\title{
Committee Independence and Financial Institution Performance during the 2007-08 Credit Crunch: Evidence from a Multi-country Study
}

\section{Yin-Hua Yeh, Huimin Chung, and Chih-Liang Liu*}

\begin{abstract}
Manuscript Type: Empirical

Research Question/Issue: Using the data of the 20 largest financial institutions from G8 countries, we explore whether the performance is higher for financial institutions with more independent directors on different committees during the 2007-08 financial crisis. We also examine the moderating effect of a country-level civil law dummy and firm-level excessive risk-taking behaviors on the independence-performance relationships.

Research Findings/Insights: The empirical evidence shows that the performance during the crisis period is higher for financial institutions with more independent directors on auditing and risk committees. The influence of committee independence on the performance is particularly stronger for civil law countries. In addition, the independenceperformance relationships are more significant in financial institutions with excessive risk-taking behaviors.

Theoretical/Academic Implications: Our findings complement existing works to partially resolve the independenceperformance relationship controversies by exploring the independence of different committees. The moderating effects of civil law countries and excessive risk-taking firms further address the governance environment's role in the effectiveness of director independence.

Practitioner/Policy Implications: Our results provide important policy implications for financial institutions. The regulation authorities should enhance regulation compliance to improve director independence, particularly for auditing and risk committees in banking industry. Independent directors in the banking industry are supposed to put more emphasis on excessive risk-taking behaviors, as the financial institutions profit from risk-bearing earnings.
\end{abstract}

Keywords: Corporate Governance, Committee Independence, Legal Origin, Excessive Risk-taking, Financial Crisis

\section{INTRODUCTION}

T his study explores whether the performance during the 2007-08 financial crisis is higher for financial institutions with more independent directors on their board committees. Using hand-collected data of financial institutions from the G8 countries, the empirical evidence shows that independence in auditing and risk committees helps improve crisis performance. We also find that such an effect is particularly significant for civil law countries, which are characterized as the legal origin with poor shareholder

*Address for correspondence: National Yunlin University of Science and Technology, no. 123, University Road, Sec. 3, Douliou, Yunlin 64002, Taiwan. Tel: 886-5-5342601; Fax: 886-5-5312079; E-mail: chlliu@yuntech.edu.tw protection practices. In addition, committee independence is found to provide higher performance for those financial institutions having more excessive risk-taking behaviors. We suggest that the effect of committee independence on financial institution performance is significant not only during the crisis, but also particularly in civil law countries and excessive risk-taking financial institutions.

Although the relationship between financial institution performance and board of directors' independence has been extensively explored, the effect of the independence from different board committees remains controversial. Since independent director appointments are prevalent in many countries, the recent global financial crisis presents a natural laboratory to examine which committee independence helps improve crisis-period performance. This study explores the 
effectiveness of independent directors on different board committees, and our evidence shows that financial institution performance during the financial crisis is positively related to the independence of auditing and risk committees.

The independence-performance relationships are affected by country-level differences. Judge, Gaur, and Muller-Kahle (2010) indicate that the effect of governance mechanisms varies in different legal system environments. Aggarwal, Erel, Stulz, and Williamson (2008) find that board independence is positively related to firm value only in countries with poor investor protections. Since ownership structure and the level of investor protection are quite different between common-law and civil-law countries (La Porta, Lopez-de-Silanes, Shleifer, \& Vishny, 1997), we therefore examine whether the relationship between committee independence and financial institution performance is influenced by their legal origins. The evidence on the positive moderating effect of a civil-law environment on the independence-performance relationships is consistent with Durnev and Kim (2005) in that firms operating under poor legal environments still have high valuations if they adopt high quality governance. Our results also confirm La Porta, Lopez-de-Silanes, Shleifer, and Vishny (1998), whereby firms seem to adapt to poor legal frameworks so as to establish better efficient governance practices.

Firm-level differences such as the level of risk-taking in the banking industry also affect the independenceperformance relationship. Since financial institutions make profits by bearing a certain level of risk, depositors and stakeholders are burdened with (un)discernible costs from the credit crunch, and exploring the failure of financial institution governance is therefore of crucial importance (Macey \& O'hara, 2003). Adams, Hermalin, and Weisbach (2010) indicate that one future topic that needs to be explored on the issue of the financial crisis is how board members matter. A board's incapability to monitor its firm's risk-taking level is the major cause for economic crises (Greenspan, 1999; Mitton, 2002; Stiglitz, 1998). One of the problems causing the 2007-09 credit crunch was excessive risk-taking behaviors. ${ }^{1}$ To understand the role of independent directors in financial institutions, we explore the moderating effect of excessive risk-taking behaviors in the independence-performance relationship. Our evidence shows that excessive risk-taking behaviors provide higher performance during the normal period of 2005-06, while the effects are inverse during the 2007-08 crisis. In addition, the independence-performance relationship is particularly significant for financial institutions with more excessive risk-taking behaviors. We provide potential contributions as follows.

First, the findings that financial institution performance is higher only for auditing and risk committees partially resolve the anomalies of the independence-performance relationship. Although previous crisis-related studies have shown that performance is lower for firms with poor governance (Baek, Kang, \& Park, 2004; Joh, 2003; Lemmon \& Lins, 2003; Mitton, 2002), these examinations are limited by the "board independence in non-financial institution" framework, and several studies find inconsistent results with different data settings. Instead of focusing on the board of directors' independence, we focus on the role of independent directors on different board sub-committees, including the auditing, nominating, compensation, and risk committees. Since each committee functions well only for specific criteria and the expertise and professions of the independent directors on different committees are varied, they can contribute to the performance from different dimensions. The independence-performance relationship therefore depends on the problems faced by the firm and the capability of the independent directors responsible for resolving it. Our results suggest that only the independence of auditing and risk committees in financial institutions helps improve their crisis-period performance.

Second, this research examines the independenceperformance relationship with multi-country settings for 2005-06 (ordinary time) and 2007-08 (financial crisis). One of the problems of governance-related studies is that the literature focuses on the relationship between performance, governance, or financial crisis under a single country only (Hagendorff, Collins, \& Keasey, 2007). In contrast, our research encompasses committee independence with multinational settings, instead of one single country.

Aside from examining the independence-performance relationship with multi-country settings, with committee independence data, and with a financial institution sample, we also partially resolve the relationship controversies by exploring the moderating effect of country- and firmlevel differences. Since governance practices vary between common-law and civil-law systems, the effectiveness of independent directors on each committee is different. We therefore examine the moderating effect of a civil-law dummy on the independence-performance relationship. The excessive risk-taking behaviors in financial institutions are also taken as the firm-level moderator. We find that the influence of committee independence on financial institution performance is particularly significant in excessive risktaking financial institutions and countries with a civil-law environment. Such evidence explains that the effects of board independence are largely different after considering various governance environments.

There are several motivations for independent directors to improve financial institution performance. First, independent directors provide not only monitoring and disciplining, but also have expertise in the decision making process. Anderson and Fraser (2000) suggest that a board's effectiveness in its monitoring function is determined by its independence. Since independent directors are in a better position to discipline management, they are expected to be more effective in prohibiting opportunistic behaviors, thereby reducing potential agency conflicts (Altunbas, Evans, \& Molyneux, 2001; Hermalin \& Weisbach, 1998; Kren \& Kerr, 1997; Ryan Jr \& Wiggins, 2004; Bebchuk, Grinstein, \& Peyer, 2010; Choi, Park, \& Yoo, 2007; Pathan, 2009). Hossain, Cahan, and Adams (2000) indicate that the value of independent directors is related to their capability of making objective decisions. We therefore suggest that independent directors can help a firm by actively providing their expert prestige and monitoring power.

The competitive directorship market in the banking industry causes independent directors to be actively concerned more about their own reputations (Pathan, 2009). Gilson (1990) finds that directors who leave distressed firms hold fewer directorships in the future. The need to maintain 
independent directors' reputation in such a labor market is therefore a major incentive for them to be effective supervisors (Fama \& Jensen, 1983; Deutsch, Keil, \& Laamanen, 2007; Judge and Zeithaml, 1992; Kesner \& Johnson, 1990). Ferris, Jaganathan, \& Pritchard (2003) also indicate that the positive performance-directorship relationship is attributed to the influence of their reputation. An independent director in financial institutions can therefore be induced by reputation incentives to be constrained from excessive risk-taking behaviors in order to improve governance mechanisms and performance (Adams \& Ferreira, 2008; Fama \& Jensen, 1983; Yermack, 2004).

Independent directors can benefit from their ownership by increasing their firm's market values. Ravina and Sapienza (2010) find that independent directors can follow informed executive's decision on change in ownership. In ordinary times, an independent director's ownership can be maximized by providing more expertise and monitoring (Beasley, 1996; Becker-Blease \& Irani, 2008; Chou, Li, \& Yin, 2010; Jensen, 1983; Shivdasani, 1993). During a financial crisis, however, funding problems make their shareholdings difficult to liquidate. The only way to reduce their loss in ownership is to actively steer the banks away from the turmoil. We therefore suggest that a committee's effectiveness can improve the firm's crisis-period performance by enhancing its downside-market protection.

During a financial crisis, independent directors can help the financial institution to improve performance by reducing excessive risk-taking behaviors. Although there are many mechanisms through which higher performance is attributed to the independent directors, the mechanisms particularly helpful in a financial crisis period are rarely explored. Ertugrul and Hegde (2008) and Pathan (2009) note that firms with more independent boards conduct less risk-taking, as independent directors may view their role as balancing between the interests of shareholders and the other stakeholders. Whidbee and Wohar (1999) also find that independent directors influence hedging decisions, suggesting that they monitor and discipline risk-taking behaviors. We therefore suggest that independent directors' risk preferences are largely different from those of other directors and executives, and independent directors in financial institutions reduce their firms' excessive risk-taking behaviors during a crisis period.

The remainder of this paper is organized as follows. Section 3 provides the theories within the extant literature with regard to the role of financial institution governance in a financial crisis. Section 3 further develops this paper's hypothesis. Section 4 presents our empirical results. Finally, the conclusions drawn from this study are in Section 5.

\section{LITERATURE AND THEORIES}

\section{Financial Institution Governance and the Financial Crisis}

Corporate governance plays an important role in financial market development and firm value around the world ( $\mathrm{La}$ Porta et al., 1997, 1998, 2000), and this is the case particularly during the time of a financial crisis. It is generally recognized that one of the main reasons for the eruption of a financial crisis is a poor governance system (Choi, 2000). In addition, the deregulation of financial institutions means the expropriation from the minority shareholders is more severe during the crisis, since the expected returns in the financial market fall (Beck, Levine, \& Levkov, 2010; Johnson, Boone, Breach, \& Friedman, 2000; Lemmon \& Lins, 2003; Mitton, 2002). As such, corporate governance provides one way to resolve the resulting economic shocks.

Governance practices affect the way in which banks expand their business activities (Illueca, Norden, \& Udell, 2009). Many large commercial banks have transitioned their main businesses away from the traditional originate-andhold lending business that relies on interest income generated from borrower-lender relationships and toward the originate-and-distribute securitization business that relies heavily on fee income (e.g., mortgage-backed securities). Such excessive risk-taking business strategies expose high risk-sensitive banks to greater systemic risk, further leading to financial stress. Since those banks responsible for origination (or securitization) do not hold any financial products that they securitize, the incentives for assessing the creditworthiness standards met by the borrowers (or correspondingly the originators) are rarely provided (Hellwig, 2009). Since both originating and securitizing institutions are more interested in volume creation than in quality control, the fee-income business therefore leads to higher revenue volatility and earnings variability (DeYoung \& Roland, 2001).

Governance practices determine the level of excessive risk-taking in financial firms (Dinc, 2005; Gorton \& Rosen, 1995). In the framework of financial institution governance, the capital markets are expected to prevent deteriorations before a crisis (Hanazaki \& Horiuchi, 2003), but their current business is extraordinarily complex and opaque (Morgan, 2002), particularly in the risk-bearing credit market. Pathan (2009) finds that banks with a less restrictive board are burdened with more excessive risks. The governance structure for bank management is therefore an important factor in its non-performing business. Similarly, Laeven and Levine (2009) indicate that banks with powerful owners will take on more risks since equity owners have stronger incentives and lower costs to benefit from bearing such higher risks. The influence of regulations on excessive risk-taking therefore depends on the governance structure, and the dependence is particularly significant for those with deposit insurance protection. Therefore, boards with better monitoring power could be helpful in steering the banks away from the turmoil.

\section{Independent Directors and Financial Crisis}

Board independence can improve financial institution governance. On the one hand, from a strategic view, independent directors provide expertise and experiences for the decision making process. Financial institutions benefit from the helpful suggestions provided by the independent directors, further reducing the likelihood of excessive risktaking behaviors. On the other hand, independent directors enhance the power of the board and its committees, thereby reducing potential agency conflicts and expropriations by the management. 
Independent directors are effective in enhancing the function of board committees. ${ }^{2}$ Mace (1971) suggests that directors serve as a source of advice, counsel, or discipline, and act in crisis situations. Similarly, Westphal (1999) and Dallas (2001) indicate that outside directors put the boards in a better position to monitor management and to assist in business decisions. For example, firms with greater board independence are more likely to fire non-performing CEOs following their poor performance (Frank, Mayer, \& Renneboog, 2001; Weisbach, 1988). Also, Dahya and McConnell (2005) note a significantly positive relationship between the likelihood of outside CEO appointment and the proportion of outside directors on the board.

Although a bank board that is responsible for protecting shareholders' interests would prefer to take on excessive risk-taking premiums (Galai \& Masulis, 1976; John, John, \& Senbet, 1991; Pathan, 2009; Saunders, Strock, \& Travlos, 1990), independent directors should be capable at effectively monitoring the excessive risks that their banks potentially take on which are underestimated. In addition, independent directors and governance mechanisms also reduce excessive risks in the absence of external regulations (Brick \& Chidambaran, 2008; Williams \& Nguyen, 2005). Prendergast (2000), Raheja (2005), and Brick and Chidambaran (2008) find a negative relationship between board monitoring and firm risk, and the monitoring is more crucial in uncertain environments. Furthermore, Erkens, Hung, and Matos (2009) present that CEO turnover is more sensitive to poor performance for firms with more independent directors. This is consistent with the argument that the role of independent directors is crucially important in a financial crisis during which regulations on credit derivatives is not comprehensive.

Recent investigations have increasingly focused on the different influences of board independence. One of the major criticisms of a corporate board is the problem of objectivity in decision making and monitoring management (Lipton \& Lorsch, 1992). Boards of directors that are more independent from management provide effective monitoring on firm management, which in turn minimizes opportunistic managerial behaviors and to discipline them so as to run the firm more efficiently (Fama \& Jensen, 1983). During a financial crisis, firms with insider-dominant boards and entrenched inside ownerships can improve performance by adding independent directors and being actively involved in major corporate affairs (Choi et al., 2007). We therefore suggest that independent directors on the board can perform their duties at providing expertise and monitoring to reduce (in)discernible costs caused by economic shocks.

\section{HYPOTHESIS DEVELOPMENT}

The apparent premise underlying the movement towards greater outside director representation is that more outside directors lead to better decisions by the board (Dahya \& McConnell, 2005). For example, several studies find a positive relationship between outside directors and corporate performance, suggesting that outside directors can protect stockholder interest by monitoring strategic decisions. ${ }^{3}$ Oxelheim and Randøy (2003) show that firms with more
Anglo-American outside board members have a higher valuation in Scandinavian stock markets. However, some of the empirical studies find a neutral relationship between board independence and performance ${ }^{4}$ and other studies in the literature even find inverse associations. ${ }^{5}$ The results on board independence and performance are inconsistent, because of the choice of variables or the data used for exploration. Our data, however, encompass the 20 largest financial institutions from each of the G8 countries, likely reducing such potential problems.

Better governance in financial institutions lead to higher performances. Berger, Clarke, Cull, Klapper, and Udell (2005) indicate that banks with better governance ownership tend to change their portfolio allocations, further leading to higher performance. Moreover, Berger et al. (2005), Adams and Mehran (2008), and Andres and Vallelado (2008) find higher performance arising from changes in banking governance. These studies suggest that a board in a financial institution not only can reduce agency conflicts, but also monitor business operations, resulting in a better performance. Independent directors also provide expertise and experience on limiting excessive risk-taking behaviors (Brick \& Chidambaran, 2008). Such a balancing act for the interests between owners and stakeholders can bring several discernible benefits and better performance.

\section{Committee Independence}

Since board committees reflect different dimensions of expertise, independent directors on different committees allow for varied involvements in representing the interests of the shareholders (Ravina \& Sapienza, 2010; Brennan \& McDermott, 2004). John and Senbet (1998) indicate that there is a strong propensity towards non-insiders serving on board committees. Klein (1998) indicates that independent directors only perform the monitoring function if they are embedded in appropriate committee structures. In the event of economic shocks, boards turn proactive, and the potential benefits of an independent board are likely to be realized (Chatterjee, Harrison, \& Bergh, 2003; Choi et al., 2007; Daily, 1996). The expertise and experiences provided by independent directors on each committee are thus crucial in helping the banks deal with crisis problems. It is therefore preferable to use our unique data to discriminate which board committees are more effective during crisis period. We suggest that independent directors on different committees contribute to financial institution governance in a varied effectiveness. In the following, we take advantage of two natural experimental settings - 2005-06 (ordinary time) and 2007-08 (credit crunch) - to examine whether bank performance increases by enhancing the independence of board committees (auditing, compensation, nominating, or risk committee).

(i) Auditing Committee. Since inside directors elected as audit committee members may be biased toward management, firms with better governance mechanisms will appoint more independent directors on the audit committee (Klein, 2002). The responsibility of an audit committee is to oversee the transparency of financial reports and ensure the objectivity of an external audit by providing a channel of 
communication (Vicknair, Hickman, \& Carnes, 1993). This committee should be free from any relationship that would interfere with independent judgment. Brick and Chidambaran (2008), Chan and Li (2008), and Aggarwal et al. (2008) find that the level of board monitoring and financial performance increase after firms have more independent directors on the audit committee. Dyck, Morse, and Zingales (2010) indicate that outside auditors are more sensitive to shareholders' needs. Therefore, we suggest that independent directors on audit committee are helpful at improving financial institution governance.

Hypothesis 1a. Financial institutions with more independent directors on the auditing committee show a better performance during the 2007-08 crisis, compared to those with fewer independent directors.

(ii) Compensation Committee. The compensation contract in which bonuses and excessive risk-taking incentives are appropriately balanced can be more likely achieved through the expertise and experiences provided by independent directors on the compensation committee. If CEO compensation includes more fixed remunerations, then a CEO may take a risk-averse attitude in selecting investment projects since the profit from those investments do not provide additional personal incentives (Guay, 1999; John, Litov, \& Yeung, 2008; May, 1995; Saunders \& Cornett, 2006). Thus, excessive risk-taking behaviors decrease after taking up a conservative investment (Demsetz \& Lehn, 1985; Kane, 1985). However, if there are more short-term equity- or option-based contracts for a bank's CEO compensation arrangement, then the $\mathrm{CEO}$ could select business projects bearing a higher level of risk in order to create greater values in their options or ownership. Bank risks are thus higher in the latter case and long-term performance is lower (Agrawal \& Mandelker, 1987; Nam, 2004). Bryan and Klein (2004) argue that independent directors provide more effective monitoring, which reduces the need for equity-based compensation for directors. We therefore suggest that independent directors on the compensation committee can improve performance during a crisis.

Hypothesis 1b. Financial institutions with more independent directors on the compensation committee show a better performance during the 2007-08 crisis, compared to those with fewer independent directors.

(iii) Nominating Committee. When there are more independent directors on the nominating committee, the board of directors is more capable of selecting higher qualified management and further monitoring the managers effectively. The Sarbanes-Oxley Act in 2002 requires nominating committees to function more effectively by enhancing the monitoring quality of directors. Mace (1971) and Patton and Baker (1987) suggest that management may inherently dominate boards through the nomination and election process. We therefore suggest that financial institutions with more independent directors on nominating committee perform better during a crisis.
Hypothesis 1c. Financial institutions with more independent directors on the nominating committee show a better performance during the 2007-08 crisis, compared to those with fewer independent directors.

(iv) Risk Committee. Financial institution governance plays an important role in risk management (BIS, 2005, 2006). The governance for risk control may not be able to provide downside-market protection if the members do not have enough information needed for assessing the risk exposures (Hellwig, 2009). Therefore, during financial crisis, the internal governance of risk control is incapable of monitoring and taking a comprehensive account of such risk exposures (Hellwig, 2009). Independent directors on risk committees, by contrast, stand in a better position against any managerial power. Free from any potential pressure, they can acquire the information needed for a risk-exposure assessment. We therefore suggest that the governance for risk control can be achieved by risk committee independence, thereby improving firm performance during a crisis.

Hypothesis 1d. Financial institutions with more independent directors on the risk committee show a better performance during the 2007-08 crisis, compared to those with fewer independent directors.

\section{Legal System Environment}

Since there are huge differences in outside director liability under varied legal rules (Black, Cheffins, \& Klausner, 2005), the national legal context may affect the independenceperformance relationship. First, ownership structure in civillaw countries is controlled by blockholders, which give them more incentives to expropriate from minority shareholders. In common-law countries, firms are controlled by managers, but owned predominately by outside shareholders, while firms in civil law countries are owned predominately by inside shareholders who also wield control over management (La Porta et al., 1997). Hence, insiderdominated civil law countries are characterized by a concentrated ownership, pyramidal structure, and family control. Independent directors in civil law countries are essential for monitoring business operations and to have supervisory functions work effectively (Mizuno \& Tabner, 2009). Aggarwal et al. (2008) find that the positive independenceperformance relationship is particularly significant when firms have controlling shareholders. We suggest that the effect of committee independence on performance is particularly higher in civil-law countries.

Second, countries with civil-law systems offer lower levels of investor rights, as well as a relationship-based systems. La Porta et al. (1997) and Barros, Ferreira, and Williams (2007) indicate that common law countries are superior to civil law nations in equity participant protection. Since firm-level governance and country-level investor protection are substitutes and firms from common law countries invest more in governance (Aggarwal et al., 2008), the role of independent directors in those countries with poor shareholder protection should be more important. They also find that board independence is positively related to firm value in countries with poor investor protections and expect that the 
independence-performance relationship is more significant in civil law countries. Based on the above arguments, we follow Durnev and Kim (2005) and Judge, Gaur, and MullerKahle (2010) to take the legal system as a moderator to explore whether the effect of committee independence on performance is particularly higher for civil-law countries.

Hypothesis 2. The positive effect of committee independence on financial institution performance is stronger in civil-law countries than in common-law countries.

\section{Excessive Risk-taking Behaviors}

Investors appear to perceive that bank boards with substantial independent director representation make better decisions and are more likely to control the damage from a financial crisis. For example, Pathan, Skully, and Wickramanayake (2008) find that improved financial institution governance is related to stock returns during a financial crisis. Cornett, Marcus, and Tehranian (2008) also note a more independent board is positively related to crisis performance of banks. Responding to the demands from the International Monetary Fund for providing a relief program, South Korean authorities addressed several policy reforms on governance mechanisms in which listed companies are required to appoint more independent directors to enhance board independence. The arguments suggest that during a financial crisis, the authorities of a board can be enhanced after outside directors become the majority on a board, further improving a firm's governance practices.

Since excessive risks taken by financial institutions are the key contributing factors to the 2007-08 financial crisis, it is interesting to understand the role of excessive risk-taking behaviors $^{1}$ in the relationship between financial institution performance and committee independence. Anderson and Fraser (2000) suggest that inside directors' preference for risk may be substantially different from that of independent directors, while Deutsch et al. (2007) suggest that due to different attitudes toward risk, a potential conflict in goals exists between shareholders and outside directors. Therefore, independent directors view themselves as taking up the role of balancing the interests of shareholders and other stakeholders (depositors or regulators), which is negatively related to a bank's excessive risk-taking (Pathan, 2009).

One of the most important policies regarding the 2007-08 credit crunch is whether financial institution boards are capable of objective judgment on risk-taking businesses (OECD, 2009a, 2009b; Rost \& Osterloh, 2010). Although Yermack (1996) suggests that firms incur costs in expanding their boards to include more outside directors, board independence is in fact costly to a firm, even as such internal governance mechanisms are crucial to prevent large losses during a crisis. Pathan (2009) finds a negative relation between independent directors and banking risks and further notes that independent directors could balance the interests of shareholders and other relevant bank stakeholders. Similarly, Whidbee and Wohar (1999) find that bankholding companies with a high proportion of equity held by independent directors are less likely to use derivatives. This suggests that the shareholdings owned by independent directors have a negative influence on the decision to use derivatives, which is consistent with Shivdasani (1993) and Subrahmanyam, Rangan, and Rosenstein (1997) that shareholdings by outside directors have an important influence on the risk decisions made by a firm. Therefore, less risktaking behaviors can be achieved by enhancing board independence in financial institutions, further leading to lower losses in a financial crisis (Illueca et al., 2009; Minton, Tailard, \& Williamson, 2010).

Committee independence helps discipline excessive risktaking behaviors, further improving firm performance. The motivations for independent directors to reduce a firm's excessive risk-taking behaviors are related to internal mechanisms and external practices. For example, independent directors are in a better position to monitor excessive risk-taking behaviors, and they are also independent from bank shareholders. Such independence results in less risktaking business (Pathan, 2009). In addition, the compensation arrangements for board directors provide varied influences on risk-taking behaviors, further affecting a bank's performance in a financial crisis (Belkhir \& Chazi, 2010; Chen \& Ma, 2011; Guo, Jalal, \& Khaksari, 2010). In other external practices, independent directors are more sensitive to regulatory compliance, and they are more likely to be concerned about any risk-taking business and riskbearing investment (Pathan, 2009). Based upon the theories in past literature, we argue that a positive relationship between committee independence and performance is more significant in financial institutions with excessive risk-taking behaviors.

Hypothesis 3. The positive effect of committee independence on performance is stronger in financial institutions with more excessive risk-taking behaviors.

\section{EMPIRICAL EVIDENCE}

\section{Data}

From the settings of the 20 largest financial institutions from each of the G8 countries (Australia, Canada, France, German, Italy, Japan, United Kingdom, and United States), the information on the board members of auditing, nominating, compensation, and risk committees is hand-collected from their annual reports from 2005 to 2008. Once the 2007-08 financial crisis occurred, the G8 countries were the fastest to respond to governance-related problems. Their statements on the financial crisis are issued at the same time with the OECD report (Corporate Governance and the Financial Crisis: Key Findings and Main Messages). In addition, four of the nations belong to the common law system (Australia, Canada, UK, and the US), while the other four belong to the civil law system (France, Germany, Italy, and Japan). We therefore select the G8 countries as our sample to examine the moderating effect of a legal system's environment on the independence-performance relationship.

Since firms listed on public stock exchanges have a greater propensity for voluntary disclosure (Collett \& Hrasky, 2005), our sample selection considers only listed financial institutions. Committee independence is labeled as the proportion of independent directors. The term "Auditing Independence" indicates the proportion of independent directors on 
the auditing committee; the term "Compensation Independence" indicates the proportion of independent directors on the compensation committee; the term "Nominating Independence" indicates the proportion of independent directors on the nominating committee; and the term "Risk Independence" indicates the proportion of independent directors on the risk committee.

Financial institution performance encompasses three proxies. Since the crisis represents an exogenous shock to individual banks, the stock returns efficiently reflect investors' perception of governance mechanisms on the market valuation. Mitton (2002) finds that firms with better governance mechanisms have higher stock returns. We therefore follow Mitton (2002), Lemmon and Lins (2003), and Baek et al. (2004) to take a bank's yearly returns of shares outstanding (Stock Returns) as the market-based performance. With regard to the accounting-based performance, the return on assets of bank $i(R O A)$ is measured by the ratio of net income to total assets, and the return on equity of bank $i(R O E)$ is measured by the ratio of net income to shareholders' equity. The variables are obtained from the OSIRIS database, with Panel A of Table 1 providing the descriptive summaries and the correlation coefficients.

Through Panel B of Table 1, we find that the financial institutions gain profits during the years 2005 to 2006, but have severe losses from 2007 to 2008. The proportions of independent directors on the board committees are particularly lower in France, because of its weak investor protection system. After discarding subsidiaries, leasing companies, and financial institutions with missing data, the final data yield 338 firm-year observations. In the following, we examine the relationship between financial institution performance and committee independence and the moderating effect of the type of legal system and excessive risk-taking behaviors.

\section{Committee Independence and Performance}

We first examine whether financial institutions with better committee independence show a better performance by adopting the OLS regressions.

$$
\begin{aligned}
\mathrm{FIP}_{\mathrm{i}}= & \alpha+\gamma_{1} \text { Auditing Independence }+\beta_{1} \text { Firm Size } \\
& +\beta_{2} \text { Equity Ratio }+\beta_{3} \text { Current Ratio }+\beta_{4} \text { Subsidiaries } \\
& +\beta_{5} \text { Margin }+\beta_{6} \text { Diversity }+\varepsilon_{\mathrm{i}}
\end{aligned}
$$

Following Saunders and Schumacher (2000), Barros et al. (2007), Valverde and Fernandez (2007), Lin and Zhang (2009), and Berger, Hasan, and Zhou (2010), the control variables include Firm Size measured by the log of total assets, Equity Ratio measured by the ratio of total equity to total assets, Current Ratio measured by the ratio of current assets to current liabilities, the Subsidiaries measured by the natural $\log$ of number of subsidiaries, Margin measured by the ratio of the difference between interest income and interest paid to total assets, and Diversity measured by the level of ownership diversity index from the BvDEP database. Terms $\alpha, \gamma$, and $\beta$ are the parameters to be estimated.

The coefficients of Auditing Independence in Table 2 are insignificant, revealing that financial institutions with more independent directors on the auditing committee may not see any improved performance. The evidence does not support Hypothesis 1a, suggesting that more independent directors on the auditing committee do not show a better performance. Hypotheses $1 \mathrm{~b}, 1 \mathrm{c}$, and $1 \mathrm{~d}$ are retested to examine the influence of other committee independence on financial institution performance by replacing Auditing Independence with Compensation Independence, Nominating Independence, or Risk Independence into Model (1). The coefficients are similarly insignificant and the results do not support Hypotheses 1b, 1c, and 1d.

\section{Committee Independence and Performance during a Crisis}

For highlighting the role of committee independence during the 2007-08 financial crisis, we examine the independenceperformance relationship by moderating the crisis period dummy.

$$
\begin{aligned}
\text { FIP } P_{i}= & \alpha+\gamma_{1} \text { Auditing Independence } * Y 0708 \\
& +\gamma_{2} \text { Auditing Independence }+\gamma_{3} Y 0708+\beta_{1} \text { Firm Size } \\
& +\beta_{2} \text { Equity Ratio }+\beta_{3} \text { Current Ratio }+\beta_{4} \text { Subsidiaries } \\
& +\beta_{5} \text { Margin }+\beta_{6} \text { Diversity }+\varepsilon_{i}
\end{aligned}
$$

We decompose the data into two periods - the subsample in ordinary times from 2005 to 2006 and the one during the credit crunch from 2007 to 2008 . Here, Y0708 is the year dummy equaling 1 if the year falls on 2007 and 2008, or 0 otherwise.

Table 3 shows that the cross-term of Y0708 and the independence of auditing and risk committees are significantly related to the financial institution performances (0.199 and 0.069 for SR; 5.039 and 1.074 for ROA; 4.802 and 8.594 for ROE), supporting Hypotheses $1 \mathrm{a}$ and $1 \mathrm{~d}$. It suggests that independent directors on the auditing and risk committees help improve financial institution performances particularly during the 2007-08 crisis. However, the coefficients for the independence of compensation and nominating committees are insignificant. We therefore argue that financial institutions with more independent auditing and risk committees have better performances during the 2007-08 credit crunch, while independent directors on other committees are of little help for improving the performance.

\section{Legal System Environment}

Since our data include different legal origin systems, their varied governance practices could bias our results. We therefore explore Hypothesis 2 by examining the moderating effect of the legal system environment on the relationship between committee independence and financial institution performance. The civil-law countries are characterized by the legal system with a concentrated ownership and a lower degree of shareholder protection. Independent directors in civil-law countries could contribute more to disciplining and monitoring the operating business, further improving performance. It is expected that committee independence in civil-law countries show a better performance during the crisis. 


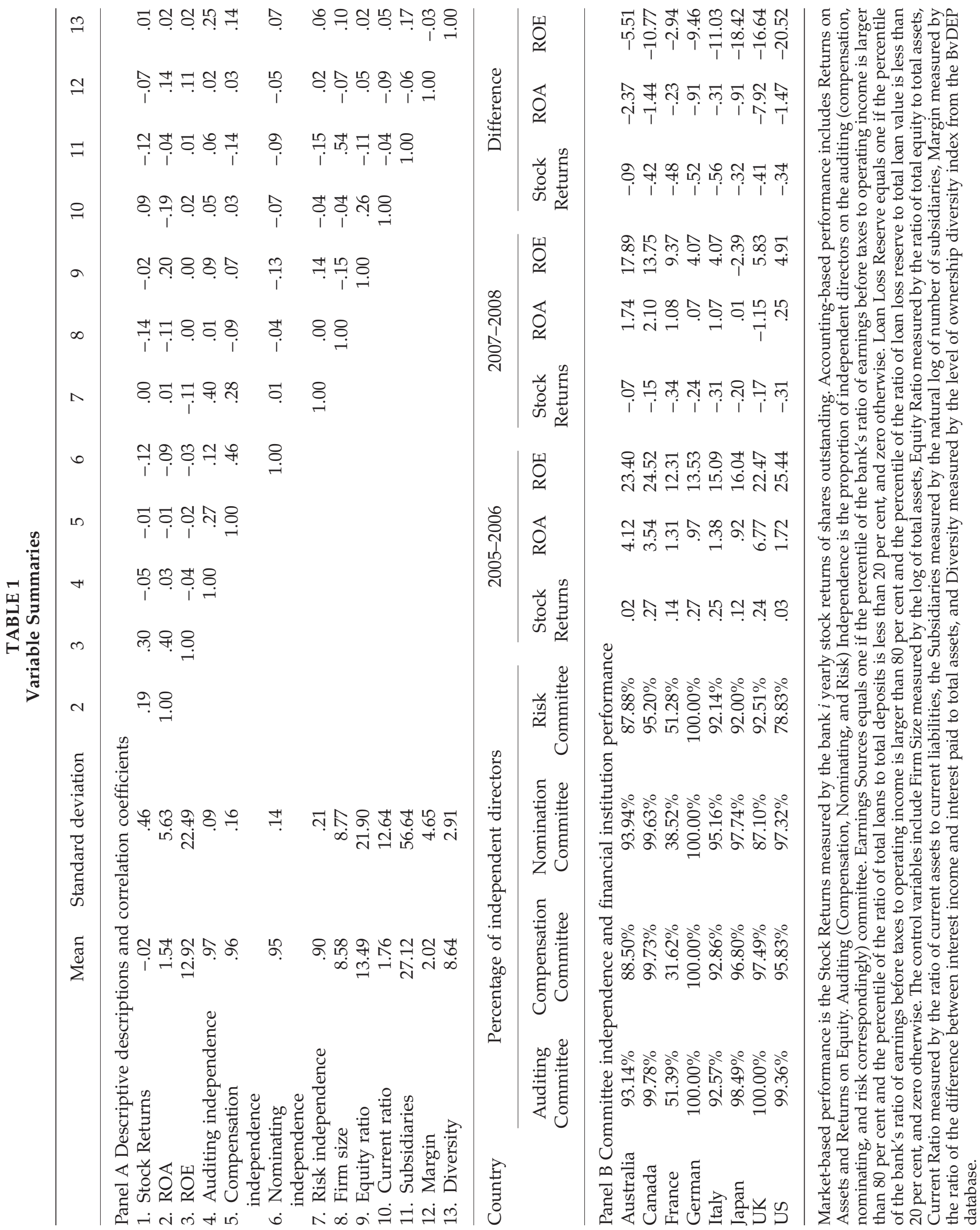




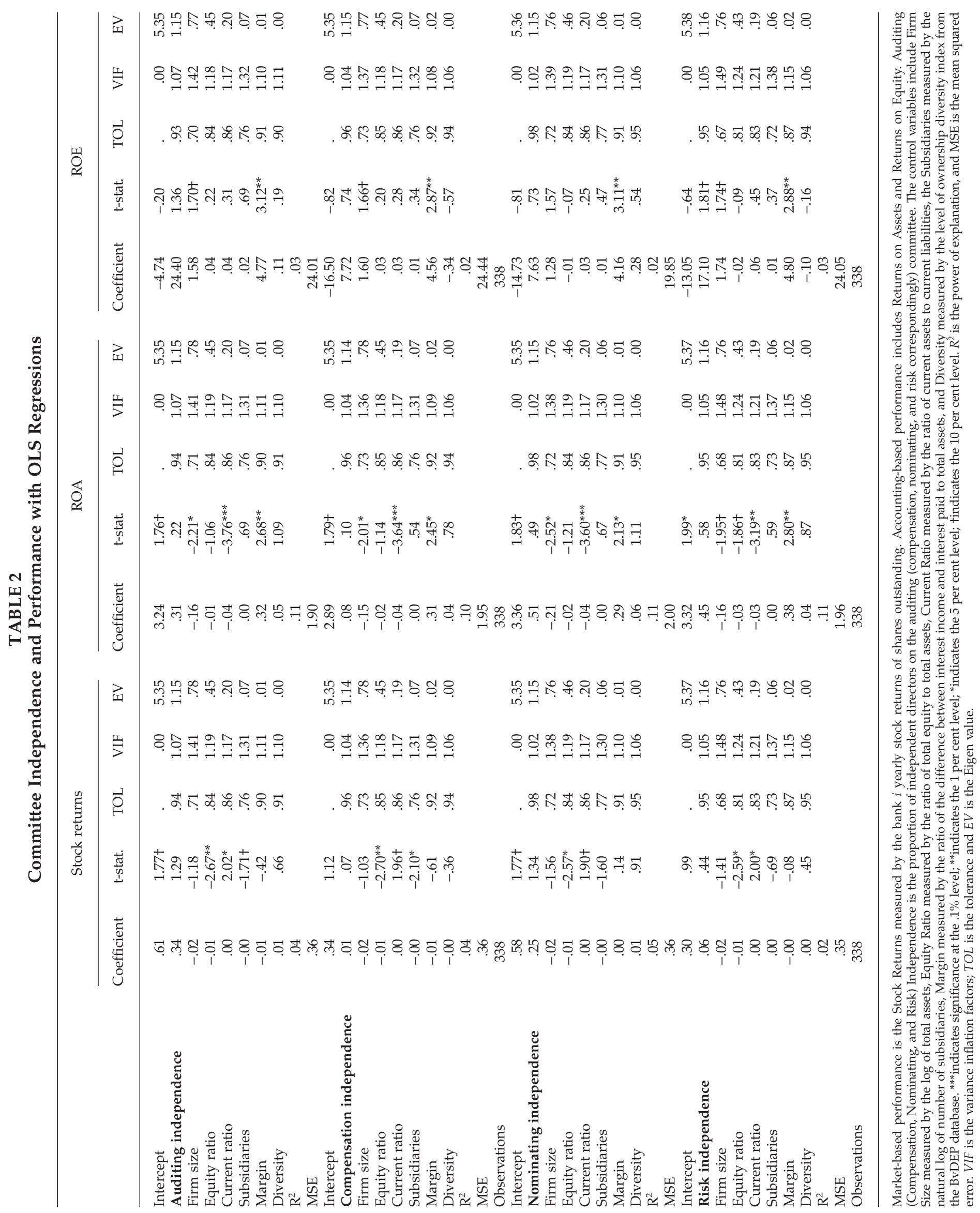




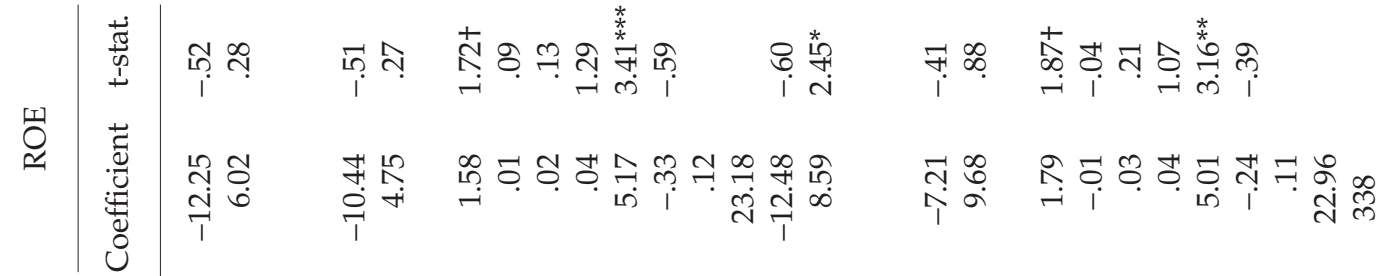

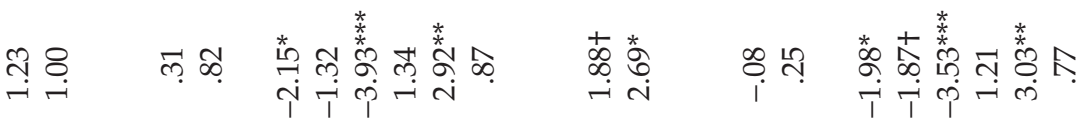

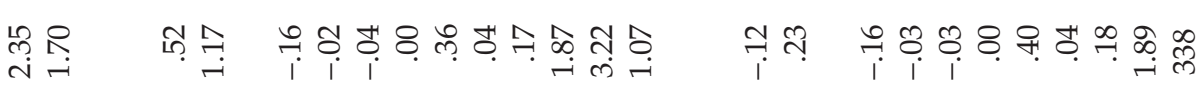

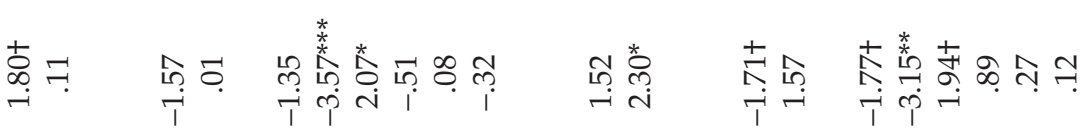

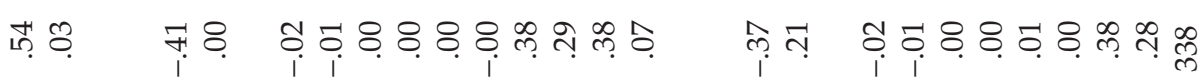

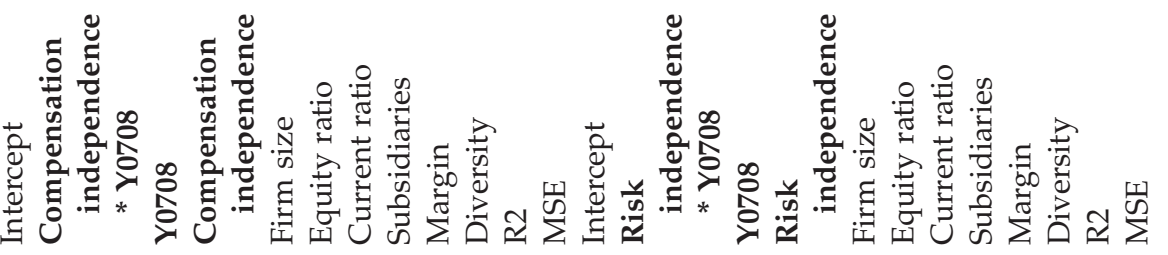

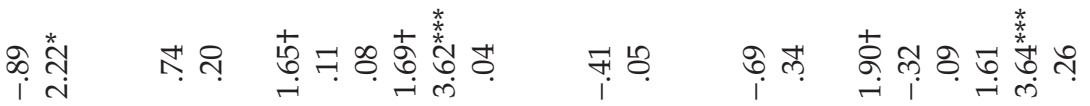

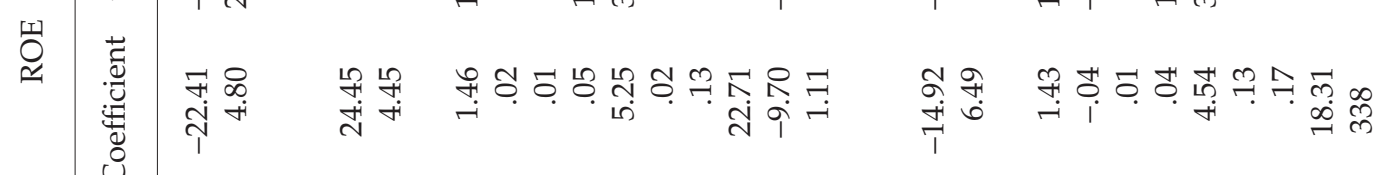

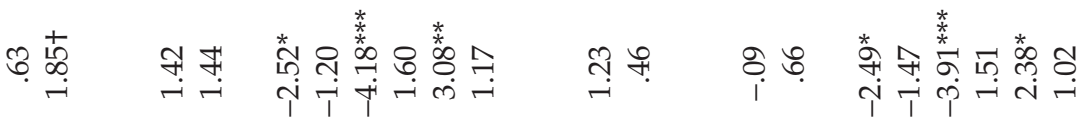

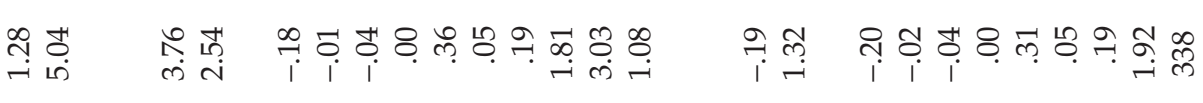

草

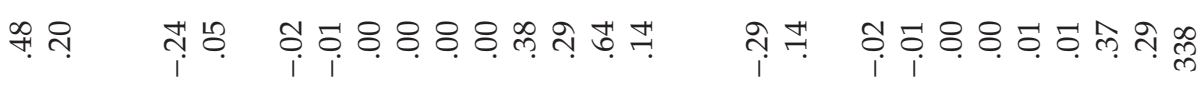

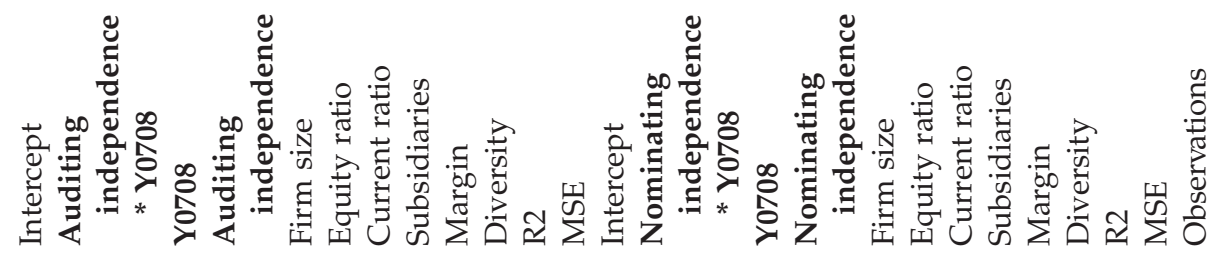

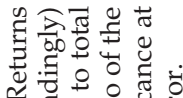

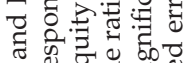

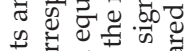

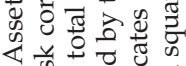

5)

施品

कo

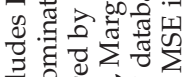

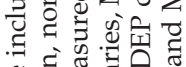

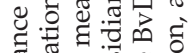

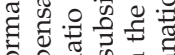

政

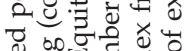

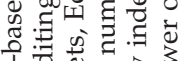

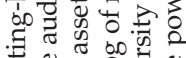

5

尊

sot

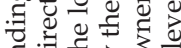

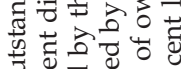

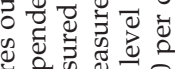

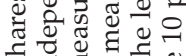

क्ष.

o

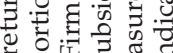

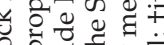

के

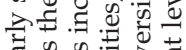

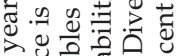

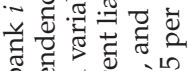

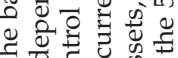

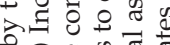

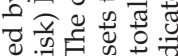

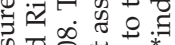

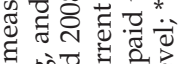

क. कृ

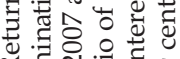

织

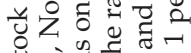

के

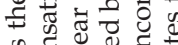

政

들

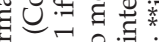

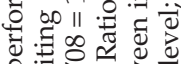

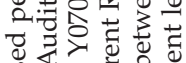

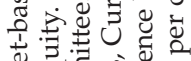




$$
\begin{aligned}
\text { FIP }_{i}= & \alpha+\gamma_{1} \text { Auditing Independence } * Y 0708 * \text { Civil } \\
& +\gamma_{2} \text { Auditing Independence }+\gamma_{3} Y 0708+\gamma_{4} \text { Civil } \\
& +\beta_{1} \text { Firm Size }+\beta_{2} \text { Equity Ratio }+\beta_{3} \text { Current Ratio } \\
& +\beta_{4} \text { Subsidiaries }+\beta_{5} \text { Margin }+\beta_{6} \text { Diversity }+\varepsilon_{i}
\end{aligned}
$$

Here, Civil equals 1 for firms belonging to civil-law countries and 0 for others belonging to common-law countries.

Table 4 shows that, during the financial crisis, financial institutions with more independent directors on the auditing and risk committees have higher stock returns and ROE, particularly for those civil-law countries practicing poor shareholder protection. The evidence supports Hypotheses $1 \mathrm{a}$ and $1 \mathrm{~d}$ that committee independence in civil-law countries is particularly helpful for improving performance during the financial crisis. However, the coefficients of the compensation and nominating committees are insignificant.

\section{Excessive Risk-taking Behaviors}

The above evidence indicates that committee independence has a positive influence on financial institution performance during the crisis, and the effects are particularly significant for the auditing and risk committees under civil law countries. Although the results indicate that committee independence improves performance and the contribution is more crucial in civil-law countries, the role of independent directors in banking risk-taking behaviors is controversial. Since the 2007-08 credit crunch is characterized with systemic risk and excessive risk-taking, it is therefore interesting to explore whether the influence of committee independence on performance is particularly significant in excessive risktaking financial institutions.

The Basel committee in recent years has suggested that financial institutions around the world adopt risk-measuring methodologies toward an "internal rating approach," instead of an inflexible "standard approach." The risk-bearing capacities are varied among different financial institutions, and we therefore adopt an indirect way to identify such excessive risk-taking behaviors. First, we include excessive risk-taking behaviours (Earnings Sources and Loan Loss Reserve) into the models. Here, Earnings Sources is the dummy equaling 1 if the percentile of the ratio of earnings before taxes to operating income $(E B T)$ is larger than 80 per cent and the percentile of the ratio of total loans to total deposits is less than 20 per cent, or 0 otherwise. Similarly, Loan Loss Reserve is the second dummy of excessive risktaking behaviors, equaling 1 if the percentile of the EBT ratio is larger than 80 per cent and the percentile of the ratio of loan loss reserves to total loan value is less than 20 per cent, or 0 otherwise.

We label Earnings Sources for the excessive risk-taking behaviors that most financial institutions faced during the 2007-08 credit crunch, because they adopted an extremely large proportion of the originate-and-distribute business. Since information on the profits or losses from the originate-and-distribute business cannot be acquired from their annual financial reports, we measure such risktaking behaviors in an indirect way. If financial institutions' earnings are extremely high and those earnings depend largely on the originate-and-distribute business, then their proportions of earnings from the originate-and-hold business are extremely lower correspondingly, thereby reducing the ratio of loans to total deposits. With regard to Loan Loss Reserve, if the financial institutions' earnings are extremely higher and the loan loss reserves are relatively low, then they are burdened with severe credit risks.

We first expect to see that the excessive risk-taking behaviors bring in large earnings in 2005-06 ordinary times, yet cause enormous losses in the 2007-08 crisis period.

$$
\begin{aligned}
\text { FIP } i= & \alpha+\gamma_{1} \text { Excessive Risk-taking }+\beta_{1} \text { Firm Size } \\
& +\beta_{2} \text { Equity Ratio }+\beta_{3} \text { Current Ratio }+\beta_{4} \text { Subsidiaries } \\
& +\beta_{5} \text { Margin }+\beta_{6} \text { Diversity }+\varepsilon_{i}
\end{aligned}
$$

Table 5 shows that the excessive risk-taking behaviors do in fact bring significantly higher performances for the financial institutions during 2005-06 (ordinary times)

$$
\begin{aligned}
\text { FIP } P_{i}= & \alpha+\gamma_{1} \text { Excessive Risk }- \text { taking } * Y 0708 \\
& +\gamma_{2} \text { Excessive Risk }- \text { taking }+\beta_{1} \text { Firm Size } \\
& +\beta_{2} \text { Equity Ratio }+\beta_{3} \text { Current Ratio }+\beta_{4} \text { Subsidiaries } \\
& +\beta_{5} \text { Margin }+\beta_{6} \text { Diversity }+\varepsilon_{i}
\end{aligned}
$$

Instead of the short-term benefits in 2005-06, the financial institutions' excessive risk-taking behaviors resulted in more severe costs and losses during the 2007-08 crisis. After including the cross term of the 2007-08 year dummy and the excessive risk-taking behaviors, Table 5 shows that the coefficients of Excessive Risk-taking * Y0708 are all significantly negative, indicating that the excessive risk-taking behaviors cause large losses for the financial institutions during the financial crisis. The evidence implies that although excessive risk-taking behaviors provide short-term profits, they lead to larger losses in the long run.

Aside from excessive risk-taking behavior being illperformed in the long run, it is interesting to explore whether the effect of committee independence on performance is more crucial in financial institutions with more excessive risk-taking behaviors. We further examine the moderating effect of excessive risk-taking behaviors on the relationship between committee independence and financial institution performance.

$$
\begin{aligned}
\text { FIP } & =\alpha+\gamma_{1} \text { Auditing Independence } * \text { Excessive Risk } \\
& - \text { taking } * Y 0708+\gamma_{2} Y 0708+\gamma_{3} \text { Auditing Independence } \\
& +\gamma_{4} \text { Excessive Risk - taking }+\beta_{1} \text { Firm Size } \\
& +\beta_{2} \text { Equity Ratio }+\beta_{3} \text { Current Ratio }+\beta_{4} \text { Subsidiaries } \\
& +\beta_{5} \text { Margin }+\beta_{6} \text { Diversity }+\varepsilon_{i}
\end{aligned}
$$

The coefficients of Auditing (Compensation, Nominating, and Risk) Independence * Excessive Risk-taking * Y0708 in Table 6 are positively significant, regardless of the market or accounting-based performance, indicating that committee independence in financial institutions with more excessive risk-taking behaviors positively influences their performance in the 2007-2008 crisis period. This result also suggests that the role of committee independence in resolving the excessive risk-taking problems is particularly significant during the crisis period, and controlling the excess-risk behaviors can effectively steer the financial institutions away from a crisis turmoil. 
TABLE 4

Committee Independence and Performance Under Different Legal Systems

\begin{tabular}{|c|c|c|c|c|c|c|}
\hline & \multicolumn{2}{|c|}{ Stock returns } & \multicolumn{2}{|c|}{$\mathrm{ROA}$} & \multicolumn{2}{|c|}{ ROE } \\
\hline & Coefficient & t-stat. & Coefficient & t-stat. & Coefficient & t-stat. \\
\hline Intercept & .54 & $1.76+$ & 4.00 & $2.04^{*}$ & 10.70 & .44 \\
\hline Auditing independence ${ }^{*} \mathrm{Y} 0708 *$ civil & .11 & $1.98^{*}$ & .60 & 1.02 & .27 & $2.13^{*}$ \\
\hline Y0708 & -.41 & $-9.51^{* * *}$ & -1.23 & $-4.50^{* * *}$ & -15.34 & $-4.51^{* * *}$ \\
\hline Auditing independence & .03 & .14 & .25 & .16 & 27.97 & 1.47 \\
\hline Civil & .02 & .24 & -.54 & -1.14 & -9.18 & -1.57 \\
\hline Firm size & -.02 & -1.46 & -.17 & $-2.38^{*}$ & 1.58 & $1.81 \dagger$ \\
\hline Equity ratio & -.01 & $-3.61^{* * *}$ & -.02 & -1.24 & .01 & .07 \\
\hline Current ratio & .00 & $2.10^{*}$ & -.04 & $-4.10^{* * *}$ & .01 & .10 \\
\hline Subsidiaries & .00 & -.20 & .00 & 1.55 & .04 & 1.49 \\
\hline Margin & .01 & .50 & .38 & $3.11^{* *}$ & 6.29 & $4.16^{* * *}$ \\
\hline Diversity & -.00 & -.11 & .03 & .72 & -.44 & -.78 \\
\hline $\mathrm{R}^{2}$ & .38 & & .18 & & .14 & \\
\hline MSE & .29 & & 1.83 & & 22.60 & \\
\hline Intercept & .47 & $1.88+$ & 3.98 & $2.47^{*}$ & -3.69 & -.19 \\
\hline Compensation independence ${ }^{*}$ Y0708 $*$ civil & .20 & $2.23^{*}$ & .56 & .97 & 2.17 & .31 \\
\hline Y0708 & -.39 & $-8.62^{* * *}$ & -1.25 & $-4.31^{* * *}$ & -15.30 & $-4.28^{* * *}$ \\
\hline Compensation independence & .05 & .37 & .28 & .33 & 9.83 & .96 \\
\hline Civil & .07 & 1.03 & -.55 & -1.26 & -7.07 & -1.33 \\
\hline Firm size & -.02 & -1.28 & -.16 & $-2.16^{*}$ & 1.61 & $1.76+$ \\
\hline Equity ratio & -.01 & $-3.57^{* * *}$ & -.02 & -1.31 & .01 & .07 \\
\hline Current ratio & .00 & $2.10^{*}$ & -.04 & $-3.96^{* * *}$ & .01 & .07 \\
\hline Subsidiaries & .00 & -.66 & .00 & 1.36 & .04 & 1.12 \\
\hline Margin & .01 & .29 & .38 & $2.97^{* *}$ & 6.01 & $3.87^{* * *}$ \\
\hline Diversity & -.00 & -.60 & .03 & .55 & -.78 & -1.30 \\
\hline $\mathrm{R}^{2}$ & .39 & & .17 & & .13 & \\
\hline MSE & .29 & & 1.87 & & 23.00 & \\
\hline Intercept & .71 & $2.53^{*}$ & 4.45 & $2.39^{*}$ & -2.82 & -.16 \\
\hline Nominating independence ${ }^{*} \mathrm{Y} 0708 *$ civil & .10 & 1.07 & .63 & 1.00 & 6.39 & 1.06 \\
\hline Y0708 & -.40 & $-8.72^{* * *}$ & -1.36 & $-4.46^{* * *}$ & -17.37 & $-5.92^{* * *}$ \\
\hline Nominating independence & .22 & 1.39 & .19 & .18 & 10.60 & 1.06 \\
\hline Civil & .02 & .23 & -.50 & -1.04 & -4.86 & -1.05 \\
\hline Firm size & -.02 & -1.59 & -.20 & $-2.59^{*}$ & 1.37 & $1.82 \dagger$ \\
\hline Equity ratio & -.01 & $-3.53^{* * *}$ & -.02 & -1.49 & -.05 & -.37 \\
\hline Current ratio & .00 & $2.05^{*}$ & -.04 & $-3.93^{* * *}$ & .00 & .05 \\
\hline Subsidiaries & .00 & -.14 & .00 & 1.56 & .04 & $1.66+$ \\
\hline Margin & .02 & .90 & .33 & $2.46^{*}$ & 4.64 & $3.63^{* * *}$ \\
\hline Diversity & .00 & .36 & .04 & .73 & .04 & .07 \\
\hline $\mathrm{R}^{2}$ & .37 & & .19 & & .17 & \\
\hline MSE & .29 & & 1.92 & & 18.29 & \\
\hline Observations & 338 & & 338 & & 338 & \\
\hline Intercept & .38 & 1.53 & 4.13 & $2.48^{*}$ & -2.66 & -.13 \\
\hline Risk independence ${ }^{*}$ Y0708 ${ }^{*}$ civil & .15 & $1.66+$ & .64 & 1.05 & 3.17 & $2.43^{*}$ \\
\hline Y0708 & -.39 & $-8.78^{* * *}$ & -1.25 & $-4.12^{* * *}$ & -14.02 & $-3.81^{* * *}$ \\
\hline Risk independence & .20 & $1.81+$ & .25 & .33 & 13.42 & 1.48 \\
\hline Civil & .05 & .68 & -.59 & -1.29 & -7.05 & -1.28 \\
\hline Firm size & -.02 & $-1.67 \dagger$ & -.17 & $-2.13^{*}$ & 1.78 & $1.87+$ \\
\hline Equity ratio & -.01 & $-3.16^{* *}$ & -.03 & $-1.89+$ & -.00 & -.01 \\
\hline Current ratio & .00 & $1.97+$ & -.04 & $-3.57^{* * *}$ & .02 & .14 \\
\hline Subsidiaries & .00 & .77 & .00 & 1.28 & .03 & .93 \\
\hline Margin & .01 & .42 & .42 & $3.13^{* *}$ & 5.73 & $3.56^{* * *}$ \\
\hline Diversity & -.00 & -.21 & .02 & .37 & -.87 & -1.31 \\
\hline $\mathrm{R}^{2}$ & .38 & & .18 & & .13 & \\
\hline MSE & .28 & & 1.89 & & 22.77 & \\
\hline Observations & 338 & & 338 & & 338 & \\
\hline
\end{tabular}

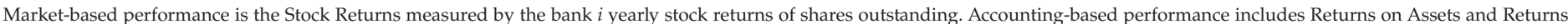

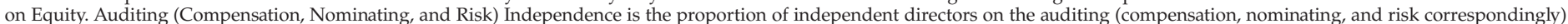

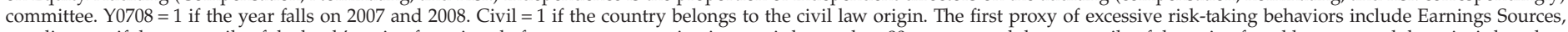

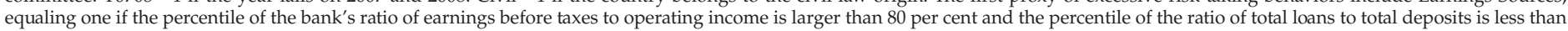

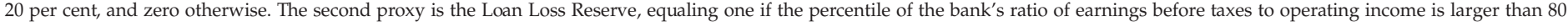

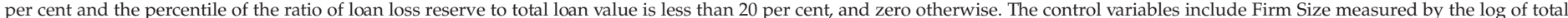

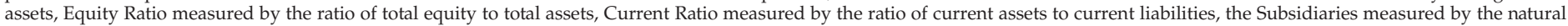

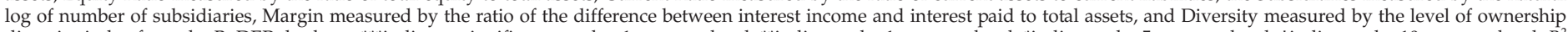

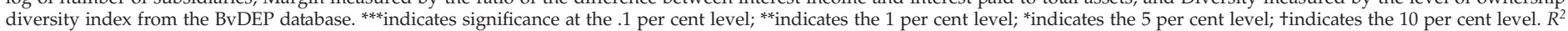
is the power of explanation, and MSE is the mean squared error. 


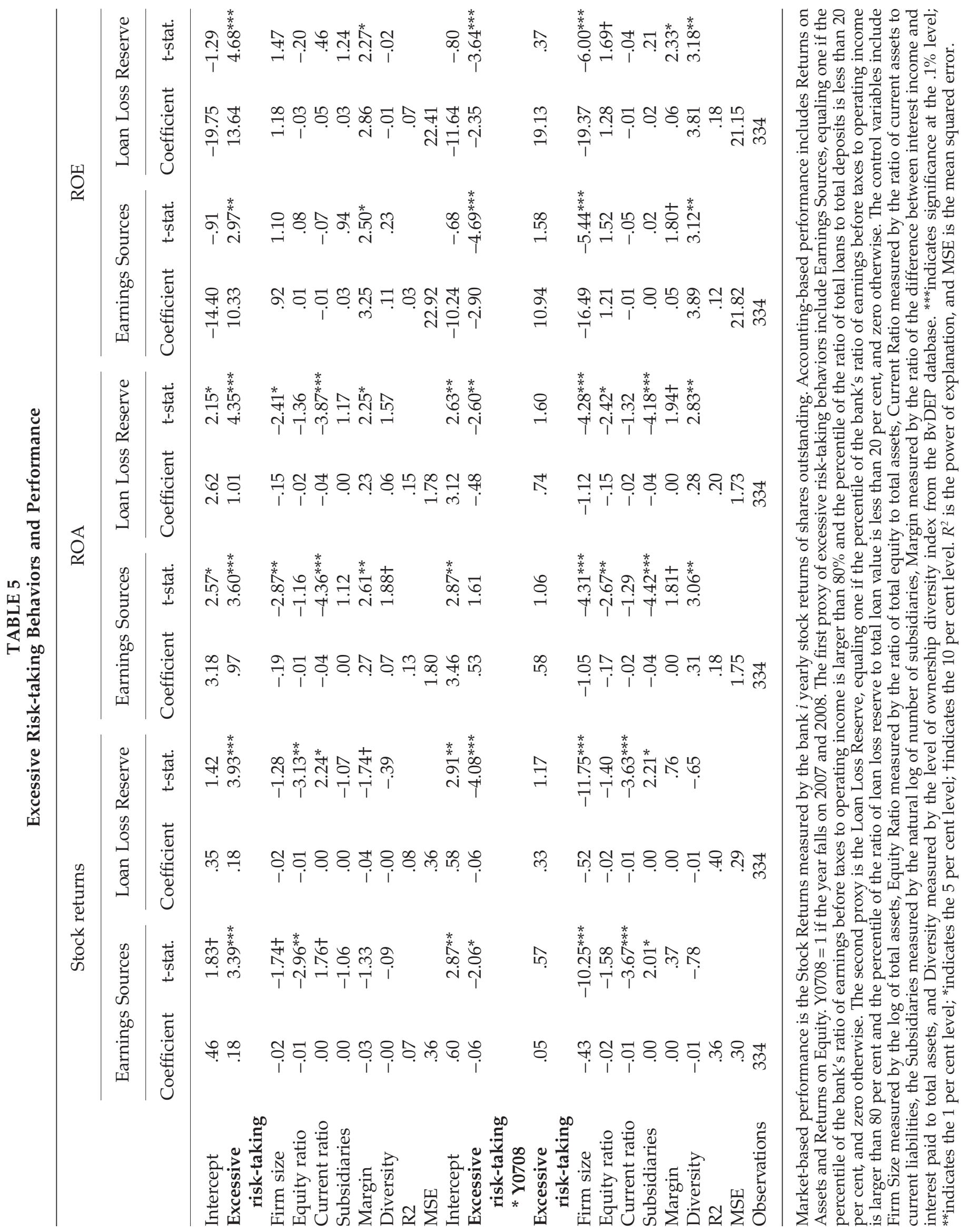


TABLE 6

Committee Independence, Excessive Risk-taking and Performance

Dependent variables: stock returns
Earnings sources as excessive risk-taking behaviors
Loan Loss reserve as excessive risk-taking behaviors

\begin{tabular}{|c|c|c|c|c|c|c|c|c|}
\hline & Coefficient & t-stat. & Coefficient & t-stat. & Coefficient & t-stat. & Coefficient & t-stat. \\
\hline Intercept & .57 & $2.05^{*}$ & .55 & $1.98^{*}$ & .56 & $2.05^{*}$ & .57 & $2.15^{*}$ \\
\hline $\begin{array}{l}\text { Auditing independence } * \text { Y0708* } \\
\text { excessive risk-taking }\end{array}$ & & & .16 & 1.60 & & & .32 & $4.02^{* * *}$ \\
\hline Y0708 & -.42 & $-11.06^{* * *}$ & -.46 & $-10.56^{* * *}$ & -.41 & $-10.67^{* * *}$ & -.52 & $-11.27^{* * *}$ \\
\hline Auditing independence & .02 & .09 & .02 & .07 & .08 & .39 & .03 & .14 \\
\hline Excessive risk-taking & .06 & 1.25 & .00 & .03 & .09 & $2.25^{*}$ & -.05 & -.86 \\
\hline Firm size & -.02 & $-1.77+$ & -.02 & -1.59 & -.02 & -1.60 & -.02 & $-1.67+$ \\
\hline Equity ratio & -.01 & $-3.73^{* * *}$ & -.01 & $-3.82^{* * *}$ & -.01 & $-3.91^{* * *}$ & -.01 & $-3.80^{* * *}$ \\
\hline Current ratio & .00 & $2.04^{*}$ & .00 & $2.22^{*}$ & .00 & $2.35^{*}$ & .00 & $2.31 *$ \\
\hline Subsidiaries & .00 & .18 & .00 & .23 & .00 & .28 & .00 & .73 \\
\hline Margin & .01 & .36 & .01 & .54 & .01 & .33 & .01 & .61 \\
\hline Diversity & .00 & .16 & .00 & .09 & .00 & .15 & .00 & .06 \\
\hline $\mathrm{R}^{2}$ & .38 & & .39 & & .39 & & .43 & \\
\hline MSE & .29 & & .28 & & .28 & & .28 & \\
\hline Intercept & .60 & $2.46^{*}$ & .58 & $2.40^{*}$ & .52 & $2.14^{*}$ & .62 & $2.67^{* *}$ \\
\hline $\begin{array}{l}\text { Compensation independence } \\
* \text { Y0708* excessive risk-taking }\end{array}$ & & & .16 & 1.57 & & & .35 & $4.15^{* * *}$ \\
\hline Y0708 & -.42 & $-10.51^{* * *}$ & -.46 & $-10.03^{* * *}$ & -.41 & $-10.30^{* * *}$ & -.53 & $-11.11^{* * *}$ \\
\hline Compensation independence & .01 & .04 & .02 & .16 & .01 & .09 & .05 & .41 \\
\hline Excessive risk-taking & .08 & 1.55 & .02 & .30 & .09 & $2.05^{*}$ & -.05 & -1.02 \\
\hline Firm size & -.02 & $-1.70 \dagger$ & -.02 & -1.50 & -.02 & -1.48 & -.02 & -1.55 \\
\hline Equity ratio & -.01 & $-3.72^{* * *}$ & -.01 & $-3.83^{* * *}$ & -.01 & $-3.84^{* * *}$ & -.01 & $-3.77^{* * *}$ \\
\hline Current ratio & .00 & $2.00^{*}$ & .00 & $2.18^{*}$ & .00 & $2.29^{*}$ & .00 & $2.29 *$ \\
\hline Subsidiaries & .00 & -.20 & .00 & -.17 & .00 & -.17 & .00 & .25 \\
\hline Margin & .01 & .24 & .01 & .41 & .00 & .15 & .01 & .52 \\
\hline Diversity & -.00 & -.35 & -.00 & -.34 & -.00 & -.47 & -.00 & -.42 \\
\hline $\mathrm{R}^{2}$ & .38 & & .39 & & .39 & & .43 & \\
\hline MSE & .29 & & .29 & & .29 & & .28 & \\
\hline Intercept & .78 & $2.93^{* *}$ & .78 & $2.94^{* *}$ & .70 & $2.68^{* *}$ & .85 & $3.28^{* *}$ \\
\hline $\begin{array}{l}\text { Nominating independence } \\
* \text { Y0708* excessive risk-taking }\end{array}$ & & & .18 & 1.61 & & & .33 & $3.68^{* * *}$ \\
\hline Y0708 & -.40 & $-9.41^{* * *}$ & -.44 & $-9.14^{* * *}$ & -.39 & $-9.35^{* * *}$ & -.50 & $-10.00^{* * *}$ \\
\hline Nominating independence & .24 & 1.60 & .25 & 1.64 & .22 & 1.47 & .26 & $1.81 \dagger$ \\
\hline Excessive risk-taking & .08 & 1.58 & .03 & .39 & .12 & $2.60 *$ & -.02 & -.30 \\
\hline Firm size & -.02 & $-1.98^{*}$ & -.02 & $-1.86+$ & -.02 & $-1.87+$ & -.02 & $-2.05^{*}$ \\
\hline Equity ratio & -.01 & $-3.70^{* * *}$ & -.01 & $-3.77^{* * *}$ & -.01 & $-3.89 * * *$ & -.01 & $-3.73^{* * *}$ \\
\hline Current ratio & .00 & $1.97 \dagger$ & .00 & $2.12^{*}$ & .00 & $2.33^{*}$ & .00 & $2.26^{*}$ \\
\hline Subsidiaries & .00 & .26 & .00 & .32 & .00 & .38 & .00 & .89 \\
\hline Margin & .02 & .86 & .02 & .98 & .02 & .76 & .02 & .94 \\
\hline Diversity & .01 & .68 & .00 & .61 & .00 & .61 & .00 & .34 \\
\hline $\mathrm{R}^{2}$ & .38 & & .38 & & .39 & & .42 & \\
\hline MSE & .29 & & .29 & & .29 & & .28 & \\
\hline Intercept & .45 & $1.89+$ & .47 & $2.25^{*}$ & .40 & $1.68+$ & .46 & $2.05^{*}$ \\
\hline $\begin{array}{l}\text { Risk independence * Y0708* } \\
\text { excessive risk-taking }\end{array}$ & & & .45 & $1.88+$ & & & .40 & $4.55^{* * *}$ \\
\hline Y0708 & -.42 & $-10.58^{* * *}$ & -.20 & $-1.85+$ & -.41 & $-10.30^{* * *}$ & -.53 & $-11.41^{* * *}$ \\
\hline Risk independence & .19 & $1.69+$ & .45 & $10.34^{* * *}$ & .17 & 1.56 & .21 & $2.03^{*}$ \\
\hline Excessive risk-taking & .07 & 1.42 & .18 & $1.69+$ & .11 & $2.57^{*}$ & -.05 & -.91 \\
\hline Firm size & -.02 & $-2.07^{*}$ & .00 & .06 & -.02 & $-1.91 \dagger$ & -.02 & $-2.23^{*}$ \\
\hline Equity ratio & -.01 & $-3.30^{* *}$ & -.02 & $-1.96+$ & -.01 & $-3.54^{* * *}$ & -.01 & $-3.61^{* * *}$ \\
\hline Current ratio & .00 & $1.89+$ & -.01 & $-3.52^{* * *}$ & .00 & $2.27^{*}$ & .00 & $2.29 *$ \\
\hline Subsidiaries & .00 & 1.17 & .00 & $2.14^{*}$ & .00 & 1.28 & .00 & $1.87+$ \\
\hline Margin & .01 & .39 & .00 & 1.22 & .01 & .41 & .01 & .68 \\
\hline Diversity & .00 & .06 & .01 & .61 & .00 & .00 & .00 & .02 \\
\hline $\mathrm{R}^{2}$ & .38 & & .39 & & .40 & & .45 & \\
\hline MSE & .28 & & .28 & & .28 & & .26 & \\
\hline
\end{tabular}


TABLE 6

Continued

Dependent variables: ROA

Earnings sources as excessive risk-taking behaviors
Loan loss reserve as excessive risk-taking behaviors

\begin{tabular}{|c|c|c|c|c|c|c|c|c|}
\hline & & \\
\hline & Coefficient & t-stat. & Coefficient & t-stat. & Coefficient & t-stat. & Coefficient & t-stat. \\
\hline Intercept & 3.40 & $1.94+$ & 3.31 & $1.89+$ & 3.24 & $1.87 \dagger$ & 3.26 & $1.89+$ \\
\hline $\begin{array}{l}\text { Auditing independence } * \text { Y0708* } \\
\text { excessive risk-taking }\end{array}$ & & & .60 & .99 & & & .73 & 1.41 \\
\hline Y0708 & -.98 & $-4.06^{* * *}$ & -1.11 & $-4.05^{* * *}$ & -.90 & $-3.71^{* * *}$ & -1.15 & $-3.84^{* * *}$ \\
\hline Auditing independence & .68 & .50 & .69 & .51 & .00 & .00 & .12 & .09 \\
\hline Excessive risk-taking & .83 & $2.84^{* *}$ & .61 & $1.66+$ & .89 & $3.48^{* * *}$ & .58 & $1.72+$ \\
\hline Firm size & -.21 & $-2.92^{* *}$ & -.20 & $-2.79^{* *}$ & -.17 & $-2.47^{*}$ & -.17 & $-2.48^{*}$ \\
\hline Equity ratio & -.02 & -1.51 & -.02 & -1.56 & -.02 & $-1.68+$ & -.02 & -1.60 \\
\hline Current ratio & -.04 & $-4.27^{* * *}$ & -.04 & $-4.13^{* * *}$ & -.03 & $-3.78^{* * *}$ & -.04 & $-3.83^{* * *}$ \\
\hline Subsidiaries & .01 & $2.07^{*}$ & .01 & $2.10^{*}$ & .01 & $2.07^{*}$ & .01 & $2.22^{*}$ \\
\hline Margin & .39 & $3.40^{* * *}$ & .41 & $3.49^{* * *}$ & .38 & $3.30^{* *}$ & .39 & $3.40^{* * *}$ \\
\hline Diversity & .04 & .83 & .03 & .79 & .04 & .85 & .03 & .81 \\
\hline $\mathrm{R}^{2}$ & .20 & & .20 & & .22 & & .22 & \\
\hline MSE & 1.80 & & 1.80 & & 1.78 & & 1.78 & \\
\hline Intercept & 3.89 & $2.53^{*}$ & 3.82 & $2.48^{*}$ & 3.04 & $1.99 *$ & 3.28 & $2.14^{*}$ \\
\hline $\begin{array}{l}\text { Compensation independence } \\
* \text { Y0708* excessive risk-taking }\end{array}$ & & & .74 & 1.15 & & & .77 & 1.40 \\
\hline Y0708 & -.98 & $-3.86^{* * *}$ & -1.14 & $-3.94^{* * *}$ & -.92 & $-3.61^{* * *}$ & -1.17 & $-3.76^{* * *}$ \\
\hline Compensation independence & .18 & .23 & .12 & .15 & .35 & .44 & .21 & .27 \\
\hline Excessive risk-taking & .84 & $2.68^{* *}$ & .57 & 1.45 & .91 & $3.37^{* * *}$ & .60 & $1.71+$ \\
\hline Firm size & -.21 & $-2.76^{* *}$ & -.20 & $-2.60^{* *}$ & -.17 & $-2.38^{*}$ & -.17 & $-2.39 *$ \\
\hline Equity ratio & -.02 & -1.55 & -.02 & -1.62 & -.02 & $-1.73+$ & -.02 & $-1.67+$ \\
\hline Current ratio & -.04 & $-4.11^{* * *}$ & -.04 & $-3.95^{* * *}$ & -.03 & $-3.65^{* * *}$ & -.03 & $-3.69^{* * *}$ \\
\hline Subsidiaries & .01 & $1.90+$ & .01 & $1.92+$ & .01 & $1.94 \dagger$ & .01 & $2.08^{*}$ \\
\hline Margin & .39 & $3.18^{* *}$ & .40 & $3.29 * *$ & .37 & $3.07^{* *}$ & .38 & $3.18^{* *}$ \\
\hline Diversity & .04 & .82 & .04 & .83 & .03 & .65 & .03 & .67 \\
\hline $\mathrm{R}^{2}$ & .19 & & .19 & & .21 & & .21 & \\
\hline MSE & 1.85 & & 1.85 & & 1.83 & & 1.83 & \\
\hline Intercept & 4.23 & $2.41^{*}$ & 4.23 & $2.41^{*}$ & 3.55 & $2.06^{*}$ & 3.81 & $2.18^{*}$ \\
\hline $\begin{array}{l}\text { Nominating independence } * \text { Y0708* } \\
\text { excessive risk-taking }\end{array}$ & & & .69 & .96 & & & .59 & .99 \\
\hline Y0708 & -1.03 & $-3.66^{* * *}$ & -1.17 & $-3.69^{* * *}$ & -.98 & $-3.54^{* * *}$ & -1.17 & $-3.47^{* * *}$ \\
\hline Nominating independence & .56 & .56 & .54 & .54 & .73 & .74 & .65 & .66 \\
\hline Excessive risk-taking & .76 & $2.23^{*}$ & .53 & 1.29 & .93 & $3.18^{* *}$ & .69 & $1.81 \dagger$ \\
\hline Firm size & -.24 & $-3.00^{* *}$ & -.23 & $-2.91^{* *}$ & -.22 & $-2.81^{* *}$ & -.22 & $-2.85^{* *}$ \\
\hline Equity ratio & -.02 & -1.65 & -.02 & $-1.68+$ & -.02 & $-1.84 \dagger$ & -.02 & $-1.77+$ \\
\hline Current ratio & -.04 & $-4.03^{* * *}$ & -.04 & $-3.92^{* * *}$ & -.04 & $-3.63^{* * *}$ & -.04 & $-3.66^{* * *}$ \\
\hline Subsidiaries & .01 & $1.92 \dagger$ & .01 & $1.95+$ & .01 & $2.04^{*}$ & .01 & $2.16^{*}$ \\
\hline Margin & .35 & $2.69^{* *}$ & .36 & $2.75^{* *}$ & .32 & $2.56^{*}$ & .33 & $2.61^{* *}$ \\
\hline Diversity & .05 & .98 & .05 & .94 & .04 & .89 & .04 & .81 \\
\hline $\mathrm{R}^{2}$ & .21 & & .21 & & .23 & & .23 & \\
\hline MSE & 1.90 & & 1.90 & & 1.87 & & 1.87 & \\
\hline Intercept & 4.22 & $2.65^{* *}$ & 4.20 & $2.63^{* *}$ & 3.48 & $2.23^{*}$ & 3.61 & $2.31^{*}$ \\
\hline $\begin{array}{l}\text { Risk independence }{ }^{*} \text { Y0708 } \\
\text { excessive risk-taking }\end{array}$ & & & .85 & 1.18 & & & .77 & 1.27 \\
\hline Y0708 & -.94 & $-3.56^{* * *}$ & -1.09 & $-3.72^{* * *}$ & -.86 & $-3.29^{* *}$ & -1.10 & $-3.42^{* * *}$ \\
\hline Risk independence & .14 & .18 & .14 & .19 & .29 & .40 & .21 & .29 \\
\hline Excessive risk-taking & .94 & $2.89^{* *}$ & .66 & 1.64 & 1.05 & $3.79 * * *$ & .75 & $2.06^{*}$ \\
\hline Firm size & -.21 & $-2.65^{* *}$ & -.20 & $-2.57^{*}$ & -.17 & $-2.22^{*}$ & -.17 & $-2.29^{*}$ \\
\hline Equity ratio & -.03 & $-2.22^{*}$ & -.03 & $-2.34^{*}$ & -.03 & $-2.48^{*}$ & -.03 & $-2.45^{*}$ \\
\hline Current ratio & -.04 & $-3.70^{* * *}$ & -.03 & $-3.50^{* * *}$ & -.03 & $-3.16^{* *}$ & -.03 & $-3.18^{* *}$ \\
\hline Subsidiaries & .01 & $1.81 \dagger$ & .01 & $1.84 \dagger$ & .01 & $1.83+$ & .01 & $1.97+$ \\
\hline Margin & .43 & $3.32^{* * *}$ & .45 & $3.45^{* * *}$ & .42 & $3.33^{* * *}$ & .43 & $3.40^{* * *}$ \\
\hline Diversity & .03 & .64 & .03 & .61 & .03 & .60 & .03 & .61 \\
\hline $\mathrm{R}^{2}$ & .21 & & .21 & & .23 & & .23 & \\
\hline MSE & 1.86 & & 1.85 & & 1.83 & & 1.83 & \\
\hline
\end{tabular}


TABLE 6

Continued

\begin{tabular}{|c|c|c|c|c|c|c|c|c|}
\hline \multirow[t]{2}{*}{ Dependent variables: ROE } & \multicolumn{4}{|c|}{$\begin{array}{l}\text { Earnings sources as excessive } \\
\text { risk-taking behaviors }\end{array}$} & \multicolumn{4}{|c|}{$\begin{array}{l}\text { Loan loss reserve as excessive } \\
\text { risk-taking behaviors }\end{array}$} \\
\hline & Coefficient & t-stat. & Coefficient & t-stat. & Coefficient & t-stat. & Coefficient & t-stat. \\
\hline Intercept & -5.22 & -.24 & -7.25 & -.33 & -4.34 & -.20 & -3.99 & -.19 \\
\hline $\begin{array}{l}\text { Auditing independence } * \text { Y0708* } \\
\text { excessive risk-taking }\end{array}$ & & & 13.60 & $1.74 \dagger$ & & & 19.89 & $3.16^{* *}$ \\
\hline Y0708 & -14.74 & $-4.84^{* * *}$ & -17.45 & $-5.12^{* * *}$ & -12.76 & $-4.22^{* * *}$ & -19.63 & $-5.34^{* * *}$ \\
\hline Auditing independence & 10.30 & .60 & 10.02 & .59 & 20.28 & 1.21 & 16.64 & 1.01 \\
\hline Excessive risk-taking & 7.80 & $2.08^{*}$ & 2.88 & .61 & 12.91 & $4.05^{* * *}$ & 4.33 & 1.05 \\
\hline Firm size & 1.20 & 1.35 & 1.38 & 1.54 & 1.45 & $1.70+$ & 1.45 & $1.73+$ \\
\hline Equity ratio & -.02 & -.12 & -.03 & -.21 & -.06 & -.41 & -.04 & -.24 \\
\hline Current ratio & .01 & .05 & .03 & .24 & .07 & .58 & .06 & .50 \\
\hline Subsidiaries & .06 & $2.00^{*}$ & .06 & $2.05^{*}$ & .07 & $2.32^{*}$ & .08 & $2.69^{* *}$ \\
\hline Margin & 5.57 & $3.85^{* * *}$ & 5.86 & $4.04^{* * *}$ & 5.52 & $3.93^{* * *}$ & 5.82 & $4.21^{* * *}$ \\
\hline Diversity & -.13 & -.25 & -.17 & -.32 & -.08 & -.15 & -.14 & -.26 \\
\hline $\mathrm{R}^{2}$ & .14 & & .15 & & .18 & & .21 & \\
\hline MSE & 22.58 & & 22.48 & & 22.03 & & 21.62 & \\
\hline Intercept & -4.67 & -.24 & -6.12 & -.32 & -13.71 & -.73 & -7.15 & -.39 \\
\hline $\begin{array}{l}\text { Compensation independence } \\
* \text { Y0708* excessive risk-taking }\end{array}$ & & & 13.74 & $1.67+$ & & & 21.01 & $3.15^{* *}$ \\
\hline Y0708 & -14.93 & $-4.68^{* * *}$ & -17.69 & $-4.94^{* * *}$ & -13.38 & $-4.25^{* * *}$ & -20.38 & $-5.35^{* * *}$ \\
\hline Compensation independence & 7.03 & .71 & 8.25 & .83 & 4.29 & .44 & 7.94 & .83 \\
\hline Excessive risk-taking & 7.80 & $1.97^{*}$ & 2.88 & .58 & 12.31 & $3.70^{* * *}$ & 3.75 & .88 \\
\hline Firm size & 1.14 & 1.22 & 1.34 & 1.43 & 1.34 & 1.50 & 1.34 & 1.53 \\
\hline Equity ratio & -.02 & -.10 & -.03 & -.21 & -.06 & -.37 & -.03 & -.22 \\
\hline Current ratio & .00 & .03 & .03 & .23 & .06 & .51 & .05 & .46 \\
\hline Subsidiaries & .05 & $1.66+$ & .05 & $1.68+$ & .06 & $1.95+$ & .07 & $2.31^{*}$ \\
\hline Margin & 5.46 & $3.62^{* * *}$ & 5.73 & $3.80^{* * *}$ & 5.37 & $3.66^{* * *}$ & 5.77 & $3.99^{* * *}$ \\
\hline Diversity & -.37 & -.67 & -.36 & -.65 & -.44 & -.80 & -.43 & -.79 \\
\hline $\mathrm{R}^{2}$ & .13 & & .14 & & .17 & & .20 & \\
\hline MSE & 22.98 & & 22.89 & & 22.49 & & 22.05 & \\
\hline Intercept & -5.98 & -.36 & -6.19 & -.37 & -11.83 & -.73 & -4.03 & -.25 \\
\hline $\begin{array}{l}\text { Nominating independence } * \text { Y0708 * } \\
\text { excessive risk-taking }\end{array}$ & & & 13.17 & $1.85+$ & & & 18.12 & $3.27^{* *}$ \\
\hline Y0708 & -14.50 & $-5.33^{* * *}$ & -16.98 & $-5.62^{* * *}$ & -12.82 & $-4.89^{* * *}$ & -18.74 & $-5.98^{* * *}$ \\
\hline Nominating independence & 6.89 & .72 & 7.16 & .75 & 4.94 & .53 & 7.37 & .81 \\
\hline Excessive risk-taking & 5.93 & $1.79+$ & 1.79 & .45 & 11.50 & $4.16^{* * *}$ & 4.07 & 1.16 \\
\hline Firm size & 1.13 & 1.47 & 1.24 & 1.62 & 1.16 & 1.59 & 1.09 & 1.54 \\
\hline Equity ratio & -.06 & -.49 & -.07 & -.56 & -.10 & -.82 & -.07 & -.60 \\
\hline Current ratio & .00 & .01 & .02 & .19 & .05 & .54 & .04 & .43 \\
\hline Subsidiaries & .05 & $1.91+$ & .05 & $1.98^{*}$ & .06 & $2.35^{*}$ & .07 & $2.83^{* *}$ \\
\hline Margin & 4.74 & $3.85^{* * *}$ & 4.92 & $4.01^{* * *}$ & 4.63 & $3.91^{* * *}$ & 4.80 & $4.14^{* * *}$ \\
\hline Diversity & .11 & .22 & .07 & .14 & .10 & .23 & -.03 & -.06 \\
\hline $\mathrm{R}^{2}$ & .18 & & .19 & & .24 & & .27 & \\
\hline MSE & 18.16 & & 18.05 & & 17.56 & & 17.15 & \\
\hline Intercept & -5.62 & -.29 & -6.13 & -.31 & -10.35 & -.54 & -7.02 & -.37 \\
\hline $\begin{array}{l}\text { Risk independence }{ }^{*} \text { Y0708 } \\
\text { excessive risk-taking }\end{array}$ & & & 13.34 & 1.46 & & & 19.94 & $2.74^{* *}$ \\
\hline Y0708 & -14.01 & $-4.30^{* * *}$ & -16.31 & $-4.52^{* * *}$ & -12.16 & $-3.79 * * *$ & -18.43 & $-4.73^{* * *}$ \\
\hline Risk independence & 12.37 & 1.37 & 12.48 & 1.39 & 14.73 & $1.67+$ & 12.53 & 1.44 \\
\hline Excessive risk-taking & 6.37 & 1.56 & 2.02 & .40 & 12.37 & $3.64^{* * *}$ & 4.48 & 1.01 \\
\hline Firm size & 1.46 & 1.51 & 1.56 & 1.60 & 1.60 & $1.73+$ & 1.49 & 1.62 \\
\hline Equity ratio & -.04 & -.21 & -.07 & -.39 & -.09 & -.58 & -.08 & -.52 \\
\hline Current ratio & .02 & .15 & .04 & .37 & .08 & .67 & .07 & .62 \\
\hline Subsidiaries & .05 & 1.37 & .05 & 1.40 & .05 & $1.67 \dagger$ & .06 & $2.01^{*}$ \\
\hline Margin & 5.20 & $3.28^{* *}$ & 5.49 & $3.45^{* * *}$ & 5.34 & $3.46^{* * *}$ & 5.57 & $3.66^{* * *}$ \\
\hline Diversity & -.31 & -.52 & -.33 & -.55 & -.29 & -.50 & -.30 & -.53 \\
\hline $\mathrm{R}^{2}$ & .12 & & .13 & & .17 & & .19 & \\
\hline MSE & 22.84 & & 22.78 & & 22.27 & & 21.92 & \\
\hline Observations & 334 & & 334 & & 334 & & 334 & \\
\hline
\end{tabular}


Table 6 Footnote Continued

Market-based performance is the Stock Returns measured by the bank $i$ yearly stock returns of shares outstanding. Accounting-based performance includes Returns on Assets and Returns on Equity. Auditing (Compensation, Nominating, and Risk) Independence is the proportion of independent directors on the auditing (compensation, nominating, and risk correspondingly) committee. Y0708 $=1$ if the year falls in 2007 and 2008. The first proxy of excessive risk-taking behaviors include Earnings Sources, equaling one if the percentile of the bank's ratio of earnings before taxes to operating income is larger than 80 per cent and the percentile of the ratio of total loans to total deposits is less than 20 per cent, and zero otherwise. The second proxy is the Loan Loss Reserve, equaling one if the percentile of the bank's ratio of earnings before taxes to operating income is larger than 80 per cent and the percentile of the ratio of loan loss reserve to total loan value is less than 20 per cent, and zero otherwise. The control variables include Firm Size measured by the log of total assets, Equity Ratio measured by the ratio of total equity to total assets, Current Ratio measured by the ratio of current assets to current liabilities, the Subsidiaries measured by the natural log of number of subsidiaries, Margin measured by the ratio of the difference between interest income and interest paid to total assets, and Diversity measured by the level of ownership diversity index from the BvDEP database. ${ }^{* * *}$ indicates significance at the .1 per cent level; ${ }^{* *}$ indicates the 1 per cent level; *indicates the 5 per tindicates the 10 per cent level. $R^{2}$ is the power of explanation, and MSE is the mean squared error.

Past literature provides inconclusive results on the relationship between board independence and firm performance. This controversy may be due to the variation in data settings or the governance environment. Based on this line of research, we explore the value of independent directors on different committees. Since board committees have different functions and responsibilities, independent directors on board committees could provide different dimensions of professions as well as expertise to resolve crisis problems, thereby efficiently improving their firm's performance. Our results reveal that banks with more independent directors on the auditing and risk committees show a higher financial institution performance during the crisis, and the higher value of independent directors is particularly significant in civil law countries. In addition, the independenceperformance relationship is also stronger in financial institutions with excessive risk-taking behaviors.

\section{DISCUSSION AND CONCLUSION}

In this study we answer the research question of whether independent directors on different committees improve financial institution performance during the 2007-08 financial crisis. Using the 20 largest financial institutions from the G8 countries, the proportions of independent directors on different committees are hand-collected from their financial reports. First, we examine the effect of committee independence on financial institution performance. The evidence shows that the relationships between performance and independence are insignificant. The next question is which value of committee independence is particularly higher during the crisis period. After including the year dummies, the independence of both the auditing and risk committees are found to have positive influences on performance during the crisis.

We also include country-level and firm-level dummies to explore whether the independence-performance relationship varies under different governance environments. Since the civil-law system is characterized as the legal origin with weak shareholder protection and concentrated ownership, we examine the moderating effect of the civil law dummy on the independence-performance relationship. We find that the influence of committee independence on financial institution performance is particularly significant in civil-law countries, suggesting that independent directors in civillaw countries adapt to their governance environment to actively improve their governance practices, further effectively improving performance during a crisis.
The two dummy proxies of firm-level excessive risktaking behaviors (Earnings Sources and Loan Loss Reserve) are also taken as the moderator. Here, Earnings Sources is the dummy equaling 1 if the percentile of the ratio of earnings before taxes to operating income (EBT) is larger than 80 per cent and the percentile of the ratio of total loans to total deposits is less than 20 per cent. Similarly, Loan Loss Reserve is the second dummy of excessive risk-taking behaviors, equaling 1 if the percentile of the EBT ratio is larger than 80 per cent and the percentile of the ratio of loan loss reserves to total loan value is less than 20 per cent. We find that financial institutions with more independent committees show a better performance during the 2007-2008 crisis, suggesting that during the financial crisis, the influences of committee independence on performance are stronger in financial institutions with excessive risk-taking behaviors.

When discussing the independence-performance relationships, the roles of independent directors' expertise (experiences or professions) are unexplored. This could explain the independence-performance relationship by specifically indicating the mechanisms through which the changes in performance are determined by director independence or how independent directors improve performance. For example, the narrative discussions on directors' expertise and experiences provided in financial annual reports are helpful for understanding whether the professions of independent directors satisfy the needs of certain committee to foresee any potential risks. In addition, the data used in our study encompass only parts of the banking industry. Whether the effectiveness of committee independence can be generalized and applied to other industries or to all countries can be reexamined. Those issues are left for future research.

Based on the positive relationship between committee independence and firm performance during the crisis, financial institutions are supposed to enhance board independence, particularly for their auditing and risk committees. During this current post-crisis period, the authorities should actively respond to governance practices by enhancing regulation compliance. Currently, for example, the regulations on risk management are weak, and the requirements put upon financial firms are not severely enforced. Policy makers should reexamine the role and the authority of independent directors to enhance their monitoring power and disciplining practices, which would further reduce excessive risk-taking behaviors, particularly for the banking industry which profits from risk-bearing earnings. Although weak shareholder protection practices and concentrated shareholdings are prevalent in civil law countries, independent 
directors can actively adapt to the governance environment to monitor their banking business, thereby improving firmlevel governance practices and crisis-period performance.

Related extensions for future research can explore other qualitative variables and interest alignment. There are other financial, organizational, operational, or strategic methods through which independent directors can help improve financial institution performance. Those potential mechanisms provide different perspectives to answer the question of how performance is influenced by director independence. The directorship market or the shares owned by independent directors are potential perspectives to understand these mechanisms. Therefore, one reasonable research question would be whether the interests of independent directors in financial institutions are aligned with shareholders (stakeholders or debt holders).

\section{ACKNOWLEDGEMENTS}

We are especially grateful to Professor William Q. Judge and two anonymous reviewers for several useful comments. In addition, we appreciate the participants of the 2010 Conference on Corporate Governance and the Global Financial Crisis.

\section{NOTES}

1. Excessive risk is defined as the risk to which the degree is in excess of the one that the financial institution is capable of bearing for its operations and business.

2. Committee independence is defined as the degree of situation in which directors are free of any material conflict of interest or any potential managerial power. In our study, committee independence is measured as the proportion of independent directors on the board committee. An independent director is defined as an outside non-executive director who is not positioned as the employer in this company, is not related to any key employees, is independent from senior management, and has never worked at the company or any of its subsidiaries, consultants, major suppliers, or customers (Hooghiemstra \& van Manen, 2004; Ajinkya, Bhojraj, \& Sengupta, 2005; Anderson, Mansi, \& Reeb, 2004; Dulewicz \& Herbert, 2004; Ertugrul \& Hegde, 2008; Kang, Cheng, \& Gray, 2007; Ravina \& Sapienza, 2010).

3. Baysinger and Butler 1985; Byrd and Hickman 1992a, 1992b; Rosenstein and Wyatt, 1990; Black, Jang, and Kim 2006; Brickley, Coles, and Jarrell 1997; Callahan, Miller, and Schilman 2003; Choe and Lee 2003; Choi et al. 2007; Chung, Wright, and Kedia 2003; Coles, Daniel, and Naveen 2008; Cornett, Marcus, and Tehranian 2008; Fich 2005; Ghosh and Sirmans 2003; Hossain et al. 2000; Kaplan and Minton 1994; Lefort and Urzua 2008; Luan and Tang 2007; Mishra and Nielsen 2000; Morck and Nakamura 1994; Oxelheim and Randøy 2003; Pearce and Zahra 1992; Ravina and Sapienza 2010; Yermack 1996.

4. Bathala and Rao 1995; Baysinger and Butler 1985; Bhagat and Black 1997, 2002; Buchholtz and Ribbens 1994; Clarke 2006; Dalton, Daily, Ellstrand, and Johnson 1998; Gilson and Kraakman 1991; Hermalin and Weisbach 1991; Hermalin and Weisbach 2003; Klein 1998; Mehran 1995; Peng 2004; Yermack 1996.

5. Agrawal and Knoeber 1996; Beatty and Zajac 1994; Bhagat and Black 2002; Chhaochharia and Grinstein 2007; Dalton et al. 1998; Hermalin and Weisbach 2003; Klein 1998; Laing and Weir 1999; Prevost, Rao, and Hossain 2002; Vafeas and Theodorou 1998; Yermack 1996.

\section{REFERENCES}

Adams, R. B. \& Ferreira, D. 2008. Regulatory pressure and bank directors' incentives to attend board meetings. Journal of Accounting and Economics, 46: 154-171.

Adams, R. B., Hermalin, B. E., \& Weisbach, M. S. 2010. The role of boards of directors in corporate governance: A conceptual framework \& survey. Journal of Economic Literature, 48: 58-107. (forthcoming).

Adams, R. B. \& Mehran, H. 2008. Corporate performance, board structure, and its determinants in the financial institutions. Working paper of Federal Reserve Bank of New York.

Aggarwal, R., Erel, I., Stulz, R., \& Williamson, R. 2008. Differences in governance practices between US and foreign firms: Measurement, causes, and consequences. Review of Financial Studies, 22: 3131-3169.

Agrawal, A. \& Knoeber, C. R. 1996. Firm performance and mechanisms to control agency problems between managers and shareholders. Journal of Financial and Quantitative Analysis, 31: 377-397.

Agrawal, A. \& Mandelker, G. 1987. Managerial incentives and corporate investment and financing decisions. Journal of Finance, 42: 823-838.

Ajinkya, B., Bhojraj, S., \& Sengupta, P. 2005. The association between outside directors, institutional investors and the properties of management earnings forecasts. Journal of Accounting Research, 43: 343-376.

Altunbas, Y., Evans, L., \& Molyneux, P. 2001. Bank ownership and efficiency. Journal of Money, Credit, and Banking, 33: 926-954.

Anderson, R. C. \& Fraser, D. R. 2000. Corporate control, bank risk taking, and the health of the banking industry. Journal of Banking $\mathcal{E}$ Finance, 24: 1383-1398.

Anderson, R., Mansi, S., \& Reeb, D. 2004. Board characteristics, accounting report integrity, and the cost of debt. Journal of Accounting and Economics, 37: 315-342.

Andres, P. \& Vallelado, E. 2008. Corporate governance in banking: The role of board of directors. Journal of Banking and Finance, 32: 2570-2580.

Baek, J. S., Kang, J. K., \& Park, K. S. 2004. Corporate governance and firm value: Evidence from the Korean financial crisis. Journal of Financial Economics, 71: 265-313.

Bank for International Settlements 2005. International convergence of capital measurement and capital standards: A revised framework. Paper discussed at the Basel Committee on Banking Supervision, Basel.

Bank for International Settlements 2006. Enhancing corporate governance for banking organizations. Paper discussed at the Basel Committee on Banking Supervision, Basel.

Barros, C. P., Ferreira, C., \& Williams, J. 2007. Analysing the determinants of performance of best and worst European banks: A mixed logit approach. Journal of Banking E Finance, 31: 21892203.

Bathala, C. T. \& Rao, R. P. 1995. The determinants of board composition: An agency theory perspective. Managerial and Decision Economics, 16: 59-69.

Baysinger, B. D. \& Butler, H. W. 1985. Corporate governance and the board of directors: Performance effects of changes in board composition. Journal of Law, Economics, and Organization, 1: 101-124.

Beasley, M. 1996. An empirical analysis of the relation between the board of director composition and financial statement fraud. Accounting Review, 71: 443-465.

Beatty, R. \& Zajac, E. 1994. Managerial incentives, monitoring, and risk bearing: A study of executive compensation, ownership, and board structure in initial public offerings. Administrative Science Quarterly, 39: 313-335. 
Bebchuk, L. A., Grinstein, Y., \& Peyer, U. 2010. Lucky CEOs and lucky directors. Journal of Finance, 65: 2363-2401.

Beck, T., Levine, R., \& Levkov, A. 2010. Big bad banks? The winners and losers from bank deregulation in the United States. Journal of Finance, 65: 1637-1667.

Becker-Blease, J. \& Irani, A. 2008. Do corporate governance attributes affect adverse selection costs? Evidence from seasoned equity offerings. Review of Quantitative Finance and Accounting, 30: 281-296.

Belkhir, M. \& Chazi, D. 2010. Corporate governance and the cost of debt: Evidence from director limited liability and indemnification provisions. Working paper of Duke University.

Berger, A. N., Clarke, G. R. G., Cull, R., Klapper, L., \& Udell, G. F. 2005. Corporate governance and bank performance A joint analysis of the static, selection, and dynamic effects of domestic, foreign, and state ownership. Journal of Banking and Finance, 29: 2179-2221.

Berger, A. N., Hasan, I., \& Zhou, M. 2010. The effects of focus versus diversification on bank performance: Evidence from Chinese banks. Journal of Banking \& Finance, 34: 14171435.

Bhagat, S. \& Black, B. S. 1997. Do independent directors matter. Working paper of Columbia University, New York.

Bhagat, S. \& Black, B. S. 2002. The non-correlation between board independence and long-term firm performance. Journal of Corporation Law, 27: 231-273.

Black, B., Cheffins, N., \& Klausner, M. 2005. Liability risk for outside directors: A cross-border analysis. European Financial Management, 11: 153-171.

Black, B. S., Jang, H., \& Kim, W. 2006. Does corporate governance predict firms' market values? Evidence from Korea. Journal of Law, Economics, E Organization, 22: 366-413.

Brennan, N. \& McDermott, M. 2004. Alternative perspectives on independence of directors. Corporate Governance: An International Review, 12: 325-336.

Brick, I. E. \& Chidambaran, N. K. 2008. Board monitoring, firm risk, and external regulation. Journal of Regulatory Economics, 33: 87-116.

Brickley, J. A., Coles, J. L., \& Jarrell, G. 1997. Leadership structure: Separating the CEO and chairman of the board. Journal of Corporate Finance, 3: 189-220.

Bryan, S. \& Klein, A. 2004. Non-management director options, board characteristics, and future firm investments and performance. Working paper of Wake Forest University.

Buchholtz, A. K. \& Ribbens, B. A. 1994. Role of chief executive officers in takeover resistance: Effects of CEO incentives and individual characteristics. Academy of Management Journal, 37: 554-579.

Byrd, J. \& Hickman, K. A. 1992a. Do outside directors monitor managers? Evidence from tender offer bids. Journal of Financial Economics, 32: 195-221.

Byrd, J. \& Hickman, K. 1992b. The case for independent outside directors. Journal of Applied Corporate Finance, 5: 78-82.

Callahan, W. T., Miller, J. A., \& Schilman, C. 2003. An analysis of the effect of management participation in director selection on the long-term performance of the firm. Journal of Corporate Finance, 9: 169-181.

Chan, K. C. \& Li, J. 2008. Audit committee and firm value: Evidence on outside top executives as expert-independent directors. Corporate Governance: An International Review, 16: 16-31.

Chatterjee, S., Harrison, J. S., \& Bergh, D. D. 2003. Failed takeover attempts, corporate governance, and refocusing. Strategic Management Journal, 24: 87-96.

Chen, Y. R. \& Ma, Y. 2011. Revisiting the risk-taking effect of executive stock options on firm performance. Journal of Business Research, 64: 640-648.
Chhaochharia, V. \& Grinstein, Y. 2007. Corporate governance and firm value: The impact of the 2002 governance rules. Journal of Finance, 62: 1789-1825.

Choe, H. \& Lee, B. S. 2003. Korean financial institution governance reform after the Asian financial crisis. Pacific-Basin Finance Journal, 11: 483-508.

Choi, J. 2000. Asian financial crisis: Financial, structural, and international dimensions. International Finance Review, 1: 3-4. Amsterdam: Elsevier.

Choi, J. J., Park, S. W., \& Yoo, S. S. 2007. The value of outside directors: Evidence from corporate governance reform in Korea. Journal of Financial and Quantitative Analysis, 42: 941962.

Chou, H. I., Li, H., \& Yin, X. 2010. The effects of financial distress and capital structure on the work effort of outside directors. Journal of Empirical Finance, 17: 300-312.

Chung, K. H., Wright, P., \& Kedia, B. B. 2003. Corporate governance and market valuation of capital and R\&D investment. Review of Financial Economics, 12: 161-172.

Clarke, D. C. 2006. The independent director in Chinese corporate governance. Delaware Journal of Corporate Law, 31: 125228.

Coles, J. L., Daniel, N. D., \& Naveen, L. 2008. Boards: Does one size fit all. Journal of Financial Economics, 87: 329-356.

Collett, P. \& Hrasky, S. 2005. Voluntary disclosure of corporate governance practices by listed Australian companies. Corporate Governance: An International Review, 13: 188-196.

Cornett, M. M., Marcus, A. J., \& Tehranian, H. 2008. Corporate governance and pay-for-performance: The impact of earnings management. Journal of Financial Economics, 87: 357-373.

Dahya, J. \& McConnell, J. J. 2005. Outside directors and corporate board decisions. Journal of Corporate Finance, 11: 3760.

Daily, C. 1996. Governance patterns in bankruptcy reorganizations. Strategic Management Journal, 17: 355-375.

Dallas, G. 2002. The new managerialism and diversity on corporate boards of directors. Tulane Law Review, 76: 1363-1408.

Dalton, D. R., Daily, C. M., Ellstrand, A. E., \& Johnson, J. L. 1998. Meta-analytic reviews of board composition, leadership structure, and financial performance. Strategic Management Journal, 19: 269-290.

Demsetz, H. \& Lehn, K. 1985. The structure of corporate ownership: causes and consequences. Journal of Political Economy, 93 : 1155-1177.

Deutsch, Y., Keil, T., \& Laamanen, T. 2007. Decision making in acquisitions: The effect of outside directors' compensation on acquisition patterns. Journal of Management, 33: 30-56.

DeYoung, R. \& Roland, K. P. 2001. Product mix and earnings volatility at commercial banks: Evidence from a degree of total leverage model. Journal of Financial Intermediation, 10: 54-84.

Dinc, I. S. 2005. Politicians and banks: Political influences on government-owned banks in emerging markets. Journal of Financial Economics, 77: 453-479.

Dulewicz, V. \& Herbert, P. 2004. Does the composition and practice of boards of directors bear any relationship to the performance of their companies. Corporate Governance: An International Review, 12: 263-280.

Durnev, A. \& Kim, E. H. 2005. To steal or not to steal: Firm attributes, legal environment, and valuation. Journal of Finance, 60: 1461-1493.

Dyck, A., Morse, A., \& Zingales, L. 2010. Who blows the whistle on corporate fraud? Journal of Finance, 66: 2213-2253. (forthcoming).

Erkens, D., Hung, M., \& Matos, P. 2009. Corporate governance in the 2007-2008 financial crisis: Evidence from financial institutions worldwide. Working paper of University of Southern California. 
Ertugrul, M. \& Hegde, S. 2008. Board compensation practices and agency costs of debt. Journal of Corporate Finance, 14: 512531.

Fama, E. \& Jensen, M. 1983. Separation of ownership and control. Journal of Law and Economics, 27: 301-325.

Ferris, S., Jaganathan, M., \& Pritchard, A. 2003. Too busy to mind the business? Monitoring by directors with multiple board appointments. Journal of Finance, 58: 1087-1111.

Fich, E. M. 2005. Are some outside directors better than others? Evidence from director appointments by Fortune 1000 firms. Journal of Business, 78: 1943-1971.

Frank, J. R., Mayer, C., \& Renneboog, L. 2001. Who disciplines management in poorly performing companies. Journal of Financial Intermediation, 10: 209-248.

Galai, D. \& Masulis, R. W. 1976. The option pricing model and the risk factor of stock. Journal of Financial Economics, 3: 5381.

Ghosh, C. \& Sirmans, C. F. 2003. Board independence, ownership structure, and performance: Evidence from real estate investment trusts. Journal of Real Estate Finance and Economics, 26: 287-318.

Gilson, S. C. 1990. Bankruptcy, boards, banks, and blockholders: Evidence on changes in corporate ownership and control when firms default. Journal of Financial Economics, 27: 355387.

Gilson, R. J. \& Kraakman, R. 1991. Reinventing the outside director: An agenda for institutional investors. Stanford Law Review, 43: 863-906.

Gorton, G. \& Rosen, R. 1995. Corporate control, portfolio choice, and the decline in banking. Journal of Finance, 50: 1377-1420.

Greenspan, A. 1999. Lessons from the global crises. Address to the World Bank group and International Monetary Fund.

Guay, W. R. 1999. The sensitivity of CEO wealth to equity risk: An analysis of the magnitude and determinants. Journal of Financial Economics, 53: 43-71.

Guo, L., Jalal, A., \& Khaksari, S. 2010. Did bank executive compensation lead to excessive risk taking and the current financial crisis. Working paper of Suffolk University.

Hagendorff, J., Collins, M., \& Keasey, K. 2007. Bank governance and acquisition performance. Corporate Governance: An International Review, 15: 957-968.

Hanazaki, M. \& Horiuchi, A. 2003. A review of Japan's bank crisis from the governance perspective. Pacific-Basin Finance Journal, 11: 305-325.

Hellwig, M. F. 2009. Systemic risk in the financial sector: An analysis of the subprime-mortgage financial crisis. De Economist, 157: 129-207.

Hermalin, B. E. \& Weisbach, M. S. 1991. The effects of board composition and direct incentives on firm performance. Financial Management, 20: 101-112.

Hermalin, B. E. \& Weisbach, M. S. 1998. Endogenously chosen boards of directors and their monitoring of the CEO. American Economic Review, 88: 96-118.

Hermalin, B. E. \& Weisbach, M. S. 2003. Board of directors as an endogenously determined institution: A survey of the economic literature. Economic Policy Review, 9: 7-26.

Hooghiemstra, R. \& van Manen, J. 2004. The independence paradox: (Im)possibilities facing non-executive directors in the Netherlands. Corporate Governance: An International Review, 12: 314-324.

Hossain, M., Cahan, S. F., \& Adams, M. B. 2000. The investment opportunity set and the voluntary use of outside directors: New Zealand evidence. Accounting and Business Research, 30: 263273.

Illueca, M., Norden, L., \& Udell, G. F. 2009. Liberalization, corporate governance, and savings banks, Working paper of Universitat Jaume I.
Jensen, M. C. 1983. Organization theory and methodology. Accounting Review, 58: 319-339.

Joh, S. W. 2003. Corporate governance and firm profitability evidence from Korea before the economic crisis. Journal of Financial Economics, 68: 287-322.

John, K., John, T. A., \& Senbet, L. W. 1991. Risk-shifting incentives of depository institutions: A new perspective on federal deposit insurance reform. Journal of Banking and Finance, 15: 895915.

John, K., Litov, L., \& Yeung, B. 2008. Corporate governance and managerial excessive risk-taking: Theory and evidence. Journal of Finance, 63: 1679-1728.

John, K. \& Senbet, L. W. 1998. Corporate governance and board effectiveness. Journal of Banking $\mathcal{E}$ Finance, 22: 371403.

Johnson, S., Boone, P., Breach, A., \& Friedman, E. 2000. Corporate governance in the Asian financial crisis, 1997-98. Journal of Financial Economics, 58: 141-186.

Judge, W. Q., Gaur, A., \& Muller-Kahle, M. I. 2010. Antecedents of shareholder activism in target firms: Evidence from a multicountry study. Corporate Governance: An International Review, 18: 258-273.

Judge, W. Q. \& Zeithaml, C. P. 1992. Institutional and strategic choice perspectives on board involvement in the strategicdecision process. Academy of Management Journal, 35: 766-794.

Kane, E. 1985. The gathering crisis in federal deposit insurance. Cambridge: MIT Press.

Kang, H., Cheng, M., \& Gray, S. J. 2007. Corporate governance and board composition diversity and independence of Australian boards. Corporate Governance: An International Review, 15: 194-207.

Kaplan, S. N. \& Minton, B. A. 1994. Appointments of outsiders to Japanese boards: Determinants and implications for managers. Journal of Financial Economics, 36: 225-258.

Kesner, I. F. \& Johnson, R. B. 1990. An investigation of the relationship between board composition and stockholder suits. Strategic Management Journal, 11: 327-336.

Klein, A. 1998. Firm performance and board committee structure. Journal of Law and Economics, 41: 275-303.

Klein, A. 2002. Audit committee, board of director characteristics, and earnings management. Journal of Accounting and Economics, 33: 375-400.

Kren, L. \& Kerr, J. K. 1997. The effect of outside directors and board shareholdings on the relation between chief executive compensation and firm performance. Accounting and Business Research, 27: 297-309.

La Porta, R., Lopez-de-Silanes, F., Shleifer, A., \& Vishny, R. 1997. Legal determinants of external finance. Journal of Finance, 52: 1131-1150.

La Porta, R., Lopez-de-Silanes, F., Shleifer, A., \& Vishny, R. 1998. Law and finance. Journal of Political Economy, 106: 11151155.

La Porta, R., Lopez-de-Silanes, F., Shleifer, A., \& Vishny, R. 2000. Investor protection and corporate governance. Journal of Financial Economics, 58: 3-27.

Laeven, L. \& Levine, R. 2009. Financial institution governance, regulation, and excessive risk-taking. Journal of Financial Economics, 93: 259-275.

Laing, D. \& Weir, C. 1999. Governance structures, size, and corporate performance in UK firms. Management Decision, 37: 457464.

Lefort, F. \& Urzua, F. 2008. Board independence, firm performance, and ownership concentration: Evidence from Chile. Journal of Business Research, 61: 615-622.

Lemmon, M. \& Lins, K. 2003. Ownership structure, corporate governance, and firm value: Evidence from the East Asian financial crisis. Journal of Finance, 58: 1445-1468. 
Lin, X. \& Zhang, Y. 2009. Bank ownership reform and bank performance in China. Journal of Banking $\mathcal{E}$ Finance, 33: 20-29.

Lipton, M. \& Lorsch, J. W. 1992. A modest proposal for improved corporate governance. Business Lawyer, 48: 59-77.

Luan, C. J. \& Tang, M. J. 2007. Where is independent director efficacy? Corporate Governance: An International Review, 15: 636-643.

Mace, M. L. 1971. Directors: Myth and reality. Boston: Harvard Business School Press.

Macey, J. R. \& O'Hara, M. 2003. The corporate governance of banks. Economic Policy Review, 9: 91-107.

May, D. O. 1995. Do managerial motives influence firm risk reduction strategies? Journal of Finance, 50: 1291-1308.

Mehran, H. 1995. Executive compensation structure, ownership, and firm performance. Journal of Financial Economics, 38: 163184.

Minton, B. A., Tailard, J. P. A., \& Williamson, R. 2010. Do independence and financial expertise of the board matter for risk taking and performance. Working paper of Ohio State University.

Mishra, C. S. \& Nielsen, J. F. 2000. Board independence and compensation policies in large bank holding companies. Financial Management, 29: 51-70.

Mitton, T. 2002. A cross-firm analysis of the impact of corporate governance on the East Asian financial crisis. Journal of Financial Economics, 64: 215-241.

Mizuno, M. \& Tabner, I. T. 2009. Corporate governance in Japan and the UK: Codes, theory, and practice. Pacific Economic Review, 14: 622-638.

Morck, R. \& Nakamura, M. 1994. Banks and corporate control in Japan. Journal of Finance, 54: 313-339.

Morgan, D. 2002. Rating banks: Risk and uncertainty in an opaque industry. American Economics Review, 92: 874-888.

Nam, S. W. 2004. Relationship banking and its role in corporate governance. Research paper of Asian Development Bank Institute.

OECD 2009a. Corporate governance and the financial crisis: Key findings and main messages. Paris: Organization for Economic Co-Operation and Development.

OECD 2009b. The financial crisis reform and exit strategies. Paris: Organization for Economic Co-Operation and Development.

Oxelheim, L. \& Randøy, T. 2003. The impact of foreign board membership on firm value. Journal of Banking and Finance, 27: 23692392.

Pathan, S. 2009. Strong boards, CEO power, and bank excessive risk-taking. Journal of Banking and Finance, 33: 1340-1350.

Pathan, S., Skully, M., \& Wickramanayake, J. 2008. Reforms in Thai financial institution governance: The aftermath of the Asian financial crisis. International Review of Financial Analysis, 17: 345-362.

Patton, A. \& Baker, J. 1987. Why do not directors rock the boat? Harvard Business Review, 65: 10-12.

Pearce, J. A. \& Zahra, S. A. 1992. Board composition from a strategic contingency perspective. Journal of Management Studies, 29: 411-438.

Peng, M. W. 2004. Outside directors and firm performance during institutional transitions. Strategic Management Journal, 25: 453471.

Prendergast, C. 2000. What trade-off of risk and incentives. American Economic Review, 90: 421-425.

Prevost, A. K., Rao, R. P., \& Hossain, M. 2002. Determinants of board composition in New Zealand: A simultaneous equations approach. Journal of Empirical Finance, 9: 373-397.

Raheja, C. G. 2005. Determinants of board size and composition: A theory of corporate boards. Journal of Financial and Quantitative Analysis, 40: 283-306.

Ravina, E. \& Sapienza, P. 2010. What do independent directors know? Evidence from their trading. Review of Financial Studies, 23: 962-1003.
Rosenstein, S. \& Wyatt, J. 1990. Outside directors, board independence, and shareholder wealth. Journal of Financial Economics, 26: 175-191.

Rost, K. \& Osterloh, M. 2010. Opening the black box of upper echelons: Drivers of poor information processing during the financial crisis. Corporate Governance: An International Review, 18: 212-233.

Ryan, H. E., Jr. \& Wiggins, R. 2004. Who is in whose pocket? Director compensation, board independence, and barriers to effective monitoring. Journal of Financial Economics, 73: 497524.

Saunders, A. \& Cornett, M. M. 2006. Financial institutions management: A risk management approach. New York: McGraw-Hill Companies Inc.

Saunders, A. \& Schumacher, L. 2000. The determinants of bank interest rate margins: An international study. Journal of International Money and Finance, 19: 813-832.

Saunders, A., Strock, E., \& Travlos, N. G. 1990. Ownership structure, deregulation, and bank excessive risk-taking. Journal of Finance, 45: 643-654.

Shivdasani, A. 1993. Board composition, ownership structure, and hostile takeover. Journal of Accounting E Economics, 16: 167198.

Stiglitz, J. 1998. The role of international financial institutions in the current global economy. Address to the Chicago Council on Foreign Relations.

Subrahmanyam, V., Rangan, N., \& Rosenstein, S. 1997. The role of outside directors in bank acquisitions. Financial Management, 26: $23-36$.

Vafeas, N. \& Theodorou, E. 1998. The relationship between board structure and firm performance in the UK. British Accounting Review, 30: 383-407.

Valverde, S. C. \& Fernandez, F. R. 2007. The determinants of bank margins in European banking. Journal of Banking $\mathcal{E}$ Finance, 31: 2043-2063.

Vicknair, D., Hickman, K., \& Carnes, K. C. 1993. A note on audit committee independence: Evidence from the NYSE on "gray" area directors. Accounting Horizons, 7: 5357.

Weisbach, M. S. 1988. Outside directors and CEO turnover. Journal of Financial Economics, 20: 431-460.

Westphal, J. D. 1999. Collaboration in the boardroom: Behavioral and performance consequences of CEO-board social ties. Academy of Management Journal, 42: 7-24.

Whidbee, D. A. \& Wohar, M. 1999. Derivative activities and managerial incentives in the banking industry. Journal of Corporate Finance, 5: 251-276.

Williams, J. \& Nguyen, N. 2005. Financial liberalization, crisis, and restructuring: A comparative study of bank performance and financial institution governance in South East Asia. Journal of Banking E Finance, 29: 2119-2154.

Yermack, D. 1996. Higher market valuation of companies with a small board of directors. Journal of Financial Economics, 40: 185-211.

Yermack, D. 2004. Remuneration, retention, and reputation incentives for outside directors. Journal of Finance, 59: 22812308.

Yin-Hua Yeh is Commissioner at the Financial Supervisory Commission and Professor of the Graduate Institute of Finance at Fu-Jen Catholic University, Taiwan. He obtained his Ph.D. in management from the National Taiwan University. His primary research interests include corporate governance, corporate finance, and mergers and acquisitions. He is the Reviewing Editor of Corporate Governance: An International Review. 
Huimin Chung is Director of the Executive MBA Program and Professor of the Graduate Institute of Finance at National Chiao Tung University, Taiwan. He obtained his Ph.D. in economics from Michigan State University. His primary research interests include corporate governance, financial economics, and derivatives. He is the Associate Editor of Corporate Governance: An International Review.
Chih-Liang Liu is Assistant Professor of Department of Finance at National Yunlin University of Science and Technology, Taiwan. He obtained his Ph.D. in management from the National Chiao Tung University. His primary research interests include corporate governance, risk management, and financial institutions. 